The University of Maine

DigitalCommons@UMaine

Publications

Senator George J. Mitchell Center for Sustainability

Solutions

Spring 4-2011

\title{
Urbanization, Water Quality, and the Regulated Landscape
}

Dave Owen

University of Southern Maine

Follow this and additional works at: https://digitalcommons.library.umaine.edu/ mitchellcenter_pubs

Part of the Environmental Law Commons, and the Environmental Policy Commons

\section{Repository Citation}

Owen, Dave, Urbanization, Water Quality, and the Regulated Landscape (April 2011). University of Colorado Law Review, Vol. 82, No. 2, 2011. Available at SSRN: https://ssrn.com/abstract=1563467 or http://dx.doi.org/10.2139/ssrn.1563467

This Article is brought to you for free and open access by DigitalCommons@UMaine. It has been accepted for inclusion in Publications by an authorized administrator of DigitalCommons@UMaine. For more information, please contact um.library.technical.services@maine.edu. 
Urbanization, Water Quality, and the Regulated Landscape

Dave Owen

Associate Professor, University of Maine School of Law 
Abstract

Watershed scientists frequently describe urbanization as a primary cause of water quality degradation, and recent studies conclude that even in lightly-developed watersheds, urbanization often precludes attainment of water quality standards. This Article considers legal responses to this pervasive problem. It explains why traditional legal measures have been ineffective, and it evaluates several recent innovations piloted in the northeastern United States. These innovations are potentially applicable across the nation. Specifically, the innovations involve using impervious cover total maximum daily loads, residual designation authority, and collective permitting to expand, intensify, and modify regulatory control of urban stormwater. More generally, the innovations involve transferring regulatory focus from end-of-the-pipe to landscape-based controls. The Article concludes that these innovations, while raising some new problems, represent a promising shift. It then discusses additional reforms and research needed to better reconcile legal water quality standards and traditional land development patterns. It also evaluates the federalism implications of this shift, and closes by considering some of the difficult prioritization questions raised by urban watershed restoration efforts.

Keywords: Urbanization, water quality, impervious cover, TMDLs, residual designation authority, watershed based permitting, federalism 


\section{INTRODUCTION}

Just southwest of Portland, Maine, an inaccurately named little stream called Long Creek flows through a typical American landscape. ${ }^{1}$ Hotels, office buildings, manufacturing plants, part of an airport, an interstate, and many smaller roadways lie interspersed within an archipelago of shopping malls. The retailers are a familiar group: though some local businesses are present, national chains predominate. Despite all the development, Long Creek remains an important community resource. Walking trails line its lower reaches, ${ }^{2}$ it empties into a small pond once popular for swimming, ${ }^{3}$ and it then flows into Casco Bay, still a distinguishing feature of the region and a driver of the local economy. ${ }^{4}$ But Long Creek is polluted, and native aquatic species are mostly gone. ${ }^{5}$ The problem is not the causes traditionally blamed for water quality degradation. The watershed contains no industrial outfalls, municipal wastewater treatment plants, or farms. ${ }^{6}$ Instead, Long Creek is polluted because the surrounding landscape, with all of its roads, roofs, and parking lots, no longer sustains water quality. ${ }^{7}$

Nearly forty years ago, Congress enacted legislation intended to protect streams like Long Creek. The Clean Water $\mathrm{Act}^{8}$ (“CWA”) requires every state to set water quality standards for rivers, lakes, coastal waterways, and streams. ${ }^{9}$ The states also must identify waters that fail to meet those standards, and the Act directs the states to use planning and permitting to ensure that degraded waters come into compliance. ${ }^{10}$ Other environmental laws, like the Endangered Species Act ("ESA") and a variety of state and local requirements, provide additional protection. ${ }^{11}$ But despite these laws, and notwithstanding some dramatic water quality improvements, ${ }^{12}$ thousands of waterways across the nation still fail to meet water quality standards. ${ }^{13}$ Problems remain in 
water bodies of all types, but they are particularly prevalent in city, suburban, and suburbanfringe streams (all of which, for simplicity, this Article just refers to as "urban streams"14). Most, if not nearly all, of these streams have poor water quality. ${ }^{15}$ The consequences are problematic: native biodiversity suffers; pollution migrates downstream to lakes, rivers, and the ocean; communities lose aesthetic and recreational benefits from some of their most accessible waterways; and landowners face substantial financial liabilities. ${ }^{16}$

This problem is not new; for years, watershed scientists have known the poor condition of urban watersheds ${ }^{17}$ Nor are scientists ignorant of the underlying causes. While degradation typically derives from the combined influence of multiple stressors, a growing body of scientific literature implicates stormwater runoff ${ }^{18}$ from impervious surfaces—roads, parking lots, and roofs, primarily—as a key factor in water quality degradation. ${ }^{19}$ Physical solutions do exist. While uncertainty remains about the effectiveness of many measures, researchers have identified a wide variety of prevention and mitigation measures. ${ }^{20}$ Watershed scientists still do not fully understand the mechanisms of harm, ${ }^{21}$ but enough is known to start solving the problem.

Finding a legal fix has proven difficult, however. The CWA's primary permitting program, the National Pollutant Discharge Elimination System ("NPDES"), has been successful on other fronts but has achieved limited progress in controlling stormwater pollution. ${ }^{22}$ The Act's backup approach — a series of planning and permitting requirements beginning with the development of pollution budgets, or "total maximum daily loads" ("TMDLs") — has done little to address any sort of water pollution, ${ }^{23}$ and faces particularly acute problems when applied to urban 
stormwater. ${ }^{24}$ Other potential legal remedies, like the Endangered Species Act, state water quality laws, and local land use regulations, have helped in some locales but more often have had little or no effect. ${ }^{25}$ All of these regulatory approaches do provide platforms for innovative and highly motivated regulators to act, but none has provided a consistent spur to action when state and local governments are preoccupied with other priorities, as is often the case. Consequently, the water quality problems created by urbanization remain largely unsolved.

That may be starting to change. A variety of regulatory innovations, many within existing statutory frameworks, suggest the possibility of an emergent approach to addressing urban stormwater pollution. ${ }^{26}$ This approach would involve dramatically expanding the scope of NPDES permitting requirements; ${ }^{27}$ relying on permitting and funding approaches that allow watershed-scale restoration planning; ${ }^{28}$ and expanding the regulatory focus beyond end-of-thepipe controls to increased regulation of development patterns. ${ }^{29}$ Many of the innovations are in their nascent stages, and a fully integrated framework has yet to emerge. ${ }^{30}$ But, in combination, the innovations could create a more effective system for protecting urban water quality. That system would focus directly on the relationship between development patterns and environmental quality, apply across much of the American landscape, and, importantly, be backed by potential federal or citizen enforcement.

With that potential change come questions. Scientists may increasingly recognize links between development patterns and water quality, and regulators might respond by integrating local land use controls into federally-mandated permitting systems. But political, judicial, and academic 
rhetoric continues to espouse the ideal of local control, with federal environmental law often portrayed as a rigid, economically inefficient, overly litigious, and fundamentally antidemocratic force. ${ }^{31}$ That rhetoric is particularly prevalent when land use is at issue. ${ }^{32}$ The continued prevalence of these anti-federal views suggests that many powerful lawmakers would resist allowing the CWA to constrain land use decisions, particularly if the constraints are activated through citizen petitions and lawsuits.

The shift in regulatory focus also raises questions about environmental priorities. Urban watershed restoration is expensive, ${ }^{33}$ and small urban streams, while sometimes important, are rarely the signature environmental features that define a community's sense of identity. Scientists and engineers also question the extent to which heavily urbanized watersheds can be restored, ${ }^{34}$ and preventing degradation in lightly urbanized watersheds usually costs much less than restoring streams in already built-out areas. ${ }^{35}$ However, even small watersheds can provide significant ecosystem services, ${ }^{36}$ and pollution can migrate downstream, creating major problems in larger and more visible waterways. ${ }^{37}$ Highly developed watersheds also typically contain many people. Even if restoring those streams is particularly difficult, it may be illogical and inequitable to allow environmental decay in people's backyards while protecting more pristine but less accessible watersheds. ${ }^{38}$ But difficult questions remain about the appropriate extent of restoration, which watersheds should come first, and what criteria should be used to make such judgments. 
This Article uses the story of Long Creek, and more generally the troubles of small urban watersheds, to explore these questions. But none of these issues are unique to this one little stream, or even to water quality management. In multiple ways, Long Creek offers a window into the contemporary challenges of environmental protection. Like Long Creek's pollution, many environmental problems derive from the cumulative effects of many small stressors, and the challenges of regulating such incremental harms therefore recur throughout environmental law. ${ }^{39}$ Similar federalism problems are endemic; from air quality management to endangered species protection, locally-determined development patterns routinely create tension with federal environmental mandates. ${ }^{40}$ And urban watershed protection raises foundational questions - most hotly debated but largely unresolved - about how to value environmental resources, and how to reconcile those values with the inevitability of some human alteration of natural systems. ${ }^{41}$ The list easily could go on. ${ }^{42}$ While this Article does not purport to resolve any of those debates, its discussion of small urban watersheds holds relevance for all of them.

The Article proceeds as follows. Part II summarizes the mechanisms of degradation of urban streams and then explains why the existing legal regime has accomplished little. Part III discusses emerging regulatory efforts to address urban watershed protection, focusing on several recent initiatives in the northeastern United States. To date, those efforts have largely occurred piecemeal, but they could and should become interconnected within a broader, integrated effort aimed at increasing regulatory focus on landscape patterns. Part IV focuses on federalism, and concludes that, in this context, the standard rhetoric is overly simplistic and not particularly constructive. This rhetoric overlooks the unavoidable interrelationships between land use patterns and environmental quality ${ }^{43}$ and rests on dubious assumptions about the necessary 
preconditions for effective, innovative governance-which, of course, is what federalism ultimately is supposed to promote.

Part $\mathrm{V}$ addresses challenges of prioritization. I map out key issues, including some concerns about the approaches to prioritization suggested by current non-legal literature, and close with suggestions for regulatory reform and future interdisciplinary research. ${ }^{44}$ The suggested reform, in a nutshell, is that under limited circumstances, the Environmental Protection Agency (the "EPA") should allow states to relax water quality standards for highly urbanized watersheds, but only when that relaxation is balanced by several state commitments, including a strong and readily enforceable program to address the water quality impact of urbanization across the rest of the landscape.

\section{URBANIZATION, DEGRADATION, AND THE LIMITS OF TRADITIONAL REGULATION}

To understand why urban water pollution poses a persistent legal challenge, one must first understand something about the mechanisms of degradation. This section therefore briefly ${ }^{45}$ explains the underlying biophysical causes of degradation and then discusses why traditional legal mechanisms have not effectively addressed those causes.
A. "Urban Stream Syndrome"46 
Urbanized watersheds typically have very different hydrology from undeveloped watersheds. In the latter, some precipitation does not reach the ground and instead remains on leaves, branches, or grass. ${ }^{47}$ The rest typically lands on porous surfaces - either partly decayed leaves and duff or in meadows with matted layers of live and dead grass - which allow infiltration into the ground but impede surface flow. ${ }^{48}$ Once in the ground, some water is absorbed into root systems and transpired by plants, some remains as soil moisture, and the rest percolates downward to the water table. ${ }^{49}$ It then flows laterally, usually at a very slow rate, until it discharges to surface waters. ${ }^{50}$ Only in larger storm events, when the rate of precipitation exceeds the ground's capacity for infiltration or on landscapes with abundant bedrock or hard-packed soils, does precipitation produce significant quantities of surface runoff. ${ }^{51}$

In several ways, that natural flow regime supports surface water quality. While surface flows tend to warm or cool to ambient surface temperatures, which vary widely over seasons and even days, subsurface conditions vary little, and streams recharged primarily by groundwater flow therefore have relatively stable temperatures. ${ }^{52}$ Shade vegetation creates a similar moderating effect, and trees also promote habitat diversity when they fall into waterways. ${ }^{53}$ An undeveloped landscape usually contains few pollutant sources, and some of the pollution carried with precipitation or deposited on the land surface filters out as water moves through the ground. ${ }^{54}$ And in undeveloped landscapes, waterways are directly connected to surrounding riparian and upland habitat, allowing species to move between habitat zones as they forage, shelter, and breed. ${ }^{55}$ For all of these reasons, the quality of waterways flowing through undeveloped landscapes tends to be quite high. 
Urbanization introduces a series of detrimental changes to that hydrology. ${ }^{56}$ Human development almost invariably increases the extent of impervious surfaces - pavement and roofs, most importantly, but also compacted soils ${ }^{57}$ - which stop water from infiltrating the ground and force it to flow overland, usually to a system of storm drains and sometimes directly to receiving waters. ${ }^{58}$ Because these overland flows move much faster than groundwater, more water reaches streams during and shortly after rainstorms, which increases, often dramatically, the frequency and intensity of high flows. ${ }^{59}$ Meanwhile, groundwater flows diminish, and less water flows into streams between storm events. ${ }^{60}$ Water extractions can exacerbate this effect; lawns and landscaped vegetation usually require irrigation, which can increase pumping from aquifers already depleted by reductions in recharge ${ }^{61}$ Consequently, urbanized watersheds frequently experience "flashy" flow, with higher flows, and often even floods, during storm events and lower or non-existent flows in dry periods. ${ }^{62}$

For a variety of reasons, the composition of urban runoff also differs from runoff in undeveloped areas. ${ }^{63}$ Urbanization adds many pollutants: lawn fertilizers and pesticides; oil and grease from cars and machinery; heavy metals scraped from brake pads and tires; salts from snow and ice treatment; sediment from construction sites; and aromatic hydrocarbons from fuel combustion, among others. ${ }^{64}$ Loading of most of these pollutants increases in proportion to the area of impervious surfaces. ${ }^{65}$ Other pollutants, like animal feces or atmospherically deposited nitrogen or mercury, occur in both urban and undeveloped areas but are more easily washed into surface waters where impervious surfaces are present. ${ }^{66}$ Temperatures ${ }^{67}$ also change; urban landscapes often warm and sometimes cool runoff, leading to both greater temperature variability than in 
undeveloped landscapes and greater stress for many aquatic species. ${ }^{68}$ Often these pollutants arrive in pulses, particularly when rain falls after extended dry periods or, in colder regions, when snow melts. ${ }^{69}$ In watersheds with combined sewers, ${ }^{70}$ the pulses are particularly pronounced; runoff from small storm events may be treated, but larger storms can overflow treatment systems and discharge mixtures of untreated stormwater and raw sewage. ${ }^{71}$

Urbanization also changes the physical structure of streams. With development, streams are often channelized, routed through culverts and dams, or even buried. ${ }^{72}$ Development often displaces riparian habitat, severing connections between streams and the surrounding habitat and removing shade vegetation. The loss of riparian vegetation limits the influx of large woody debris, which provides important habitat in healthy streams. ${ }^{73}$ Flow changes also affect the physical shape of streambeds. High flows tend to be erosive, and flashy flows will often widen and deepen a stream's bed. ${ }^{74}$ Habitat diversity typically diminishes, with riffles, pools, and bends replaced by a straighter stream with a more homogenous substrate. ${ }^{75}$

The aggregate consequence of these physical and chemical changes usually is a stream with little resemblance to a stream in an undeveloped area ${ }^{76}$ Native biodiversity decreases, with sensitive (and sometimes legally protected) ${ }^{77}$ species declining or disappearing. ${ }^{78}$ Streams can lose aesthetic appeal, with low, sluggish flows moving through wide, devegetated streambeds, except during occasional periods of high flow or flood. ${ }^{79}$ These changes are pervasive. Some survey studies conclude that water quality tends to decline when impervious surfaces cover more than 10 percent of a watershed, and that small watersheds with more than 25 percent impervious 
cover almost always exhibit highly degraded water quality. ${ }^{80}$ Even sparse ex-urban development, if spread across a watershed, will exceed the former threshold, and stream degradation therefore is a standard feature of the landscapes in which most Americans live, work, and shop. ${ }^{81}$ Other recent research suggests that impacts begin at even lower development levels; several studies have found a consistent onset of degradation at impervious cover levels below 5 percent. ${ }^{82}$ The correlation between impervious cover and degradation in larger watersheds is less clear; ${ }^{83}$ while larger watersheds are still impacted, studies have not yet tied degrees of degradation to specific levels of urbanization. ${ }^{84}$ But even with those remaining uncertainties, scientists know that thousands of urban streams, small rivers, and even larger watersheds are significantly degraded by stormwater pollution from roofs and pavement. ${ }^{85}$

While urbanization almost invariably lowers water quality, a variety of mechanisms can mitigate the effects. ${ }^{86}$ Builders can reduce the footprints of buildings and the area of roads or can substitute pervious pavement and green roofs ${ }^{87}$ for traditional road surfaces and building designs. ${ }^{88}$ Impervious surfaces can drain into infiltration swales or rain gardens rather than into storm drainage systems. ${ }^{89}$ Prohibitions on toxic products, ${ }^{90}$ educational programs, and maintenance programs like street sweeping can reduce pollutant loading. ${ }^{91}$ Uncertainties about treatment remain; few watershed-scale studies document the effectiveness of mitigation programs, and most researchers expect that no amount of planning and engineering can turn an urbanized landscape into the hydrologic equivalent of a forest. ${ }^{92}$ These solutions also cost money - particularly when they require retrofitting already developed areas - and financial constraints therefore could prevent full mitigation even if it were theoretically possible. But such 
measures, if transformed into standard practice, could slow the degradation of water quality in developing areas and improve it where development already has taken place.

\section{B. Traditional Legal Responses}

If impaired urban water quality is a pervasive problem but remedial tools exist, a logical next question is what combination of mandates and incentives will best facilitate the use of those tools. That question is largely legal, and traditional environmental laws attempt to provide some answers. But those answers have not proven particularly effective. As this section explains, neither of the CWA's two primary regulatory systems has provided anything approaching full protection against the adverse water quality effects of urbanization. Nor have other mechanisms — most notably, state regulatory systems and the federal ESA — filled the void. The picture is far from completely negative; each approach has led to some protection, and with each, the trend may be toward greater effectiveness. But still, much room for progress remains.

\section{The NPDES Program}

The CWA's primary mechanism for controlling water pollution is the National Pollutant Discharge Elimination System (NPDES). ${ }^{93}$ The system applies to "any addition of any pollutant to navigable waters from any point source," 94 and the Act defines "point source" to include most human-controlled systems for conveying pollutants directly or indirectly to surface waters- 
including most urban stormwater discharge systems. ${ }^{95}$ No such discharge may occur without a permit, ${ }^{96}$ and the permits usually specify numeric limitations on pollutant concentrations. ${ }^{97}$ Permittees must monitor their discharges,${ }^{98}$ and violations expose the permittee to governmental enforcement or citizen suits. ${ }^{99}$ Although the system has received some criticism, ${ }^{100}$ many commentators praise it, ${ }^{101}$ and most commentators at least credit the NPDES program with achieving substantial pollution reductions. ${ }^{102}$ But while highly successful in many ways, the NPDES program is widely viewed as a poor system for controlling stormwater pollution. ${ }^{103}$

One problem with the NPDES program is the difficulty of monitoring stormwater quality. ${ }^{104}$ The program works relatively well for sources like industrial outfalls or wastewater treatment plants, which involve controlled systems that produce continuous and relatively consistent effluent flows—or, if they produce spikes, do so at predictable times. ${ }^{105}$ Stormwater, by contrast, flows on nature's unpredictable schedule, and pollutant concentrations tend to vary within and between storm events, complicating sampling efforts. ${ }^{106}$ The EPA's regulations acknowledge these complications by imposing only limited sampling requirements, and many permits require little or no testing. ${ }^{107}$ Because of variations in stormwater quality, the few samples that are collected may not be representative. ${ }^{108}$

Even if comprehensive, continuous testing of stormwater effluent were possible, that testing would likely fail to reveal important data. The rate of stormwater flow can matter just as much as, if not more than, stormwater's chemical composition, for flow rates help determine stream channel morphology, temperature, erosion and associated sediment loading, and in stream flow 
levels. ${ }^{109}$ Effluent testing also may not reveal the ultimate sources of pollutants and thus may not provide permittees and regulators with sufficient information to institute effective source controls. Because dozens of properties and multiple roadways can contribute runoff to a single municipal outfall, testing revealing excessive pollutant concentrations will not indicate which properties or roads — let alone which areas within those properties or roads—are primarily to blame.

Those data shortages have led the EPA to use a different type of standard than it uses for traditional industrial or wastewater treatment plant outfalls. ${ }^{110}$ For conventional point sources, the EPA sets numeric standards that limit the concentrations of pollutants in effluent. ${ }^{111}$ Stormwater permits instead require implementation of "best management practices" (BMPs)— engineering, housekeeping, and, sometimes, educational measures designed to reduce pollutant discharges. ${ }^{112}$ Some sources also must test discharges periodically, but only infrequently, and for many potential sources, BMP implementation is the only permit requirement. ${ }^{113}$ Consequently, even if BMPs are fully implemented and carefully maintained, little or no independent oversight affirms that they are actually working. ${ }^{114}$ And while implementation and maintenance of some BMPs are easy to monitor, assessing compliance with others can be difficult, which leaves regulators and non-profit groups with little ability to verify and, if necessary, compel compliance. ${ }^{115}$ Exacerbating this problem is the discretion industrial facilities enjoy in selecting BMPs, which means that facilities may focus on pollution that can be controlled cheaply rather than pollution that causes the greatest downstream impact. ${ }^{116}$ Finally, while BMPs are typically designed to keep chemical and biological pollutants out of stormwater, other sources of degradation, like temperature increases and altered flow levels, often escape control. ${ }^{117}$ 
Adding to all of these limitations is the circumscribed applicability of the NPDES stormwater program. If stormwater does not pass through a point source - that is, if it simply runs off a site without ever passing through a ditch, pipe, or other discrete conveyance - the runoff does not meet the CWA's definition of "discharge," and does not require a NPDES permit, even if it conveys pollutants into waterways. ${ }^{118}$ Nor are all point source stormwater discharges subject to regulation. In 1987, after the EPA had struggled for years to fit stormwater into its regulatory program (after previously attempting, unsuccessfully, to avoid doing so), ${ }^{119}$ Congress amended the NPDES program to include some stormwater sources but to leave others out. ${ }^{120}$ Industrial sources, including the entire manufacturing sector, large construction sites, and larger municipal storm sewers, were to be included by $1990,{ }^{121}$ and the EPA later expanded the program to include smaller construction sites and smaller municipal systems. ${ }^{122}$ But private, non-industrial stormwater drainage systems - for example, drainage systems from shopping malls or office parks - and municipal discharges from areas that do not meet the statutory criteria, still fall outside the program unless the EPA or state regulatory authorities affirmatively act to include them. ${ }^{123}$ Until quite recently, neither the EPA nor any state authority had ever taken that step. ${ }^{124}$

The NPDES stormwater program is by no means completely ineffective. Permittees do have obligations, and while compliance data are sparse, clearly some businesses and municipalities do make substantial efforts at stormwater control. ${ }^{125}$ If a state is highly motivated to address stormwater issues, it may use its NPDES permitting authority as leverage to compel local action. ${ }^{126}$ Recent permit proposals also suggest that the EPA can use the NPDES program as a platform for developing innovative and more stringent regulatory requirements for sources 
already subject to regulatory coverage, ${ }^{127}$ and studies of stormwater management have identified the existing program as a useful starting point. ${ }^{128}$ Key elements of the program are fairly new; smaller municipal systems, for example, have been permitted only since 2003, and the program may grow more effective as permittees become more accustomed to its requirements. Nevertheless, the widespread critiques of the program and the persistence of stormwater-driven water-quality problems suggest that ample room for improvement remains.

\section{TMDLs}

While centrally important, the NPDES program is not the CWA's sole mechanism for addressing water pollution. The Act also requires states to prepare pollution budgets, or "total maximum daily load[s]" ("TMDLs"), for water bodies not likely to attain water quality standards through technology-based controls alone. ${ }^{129}$ TMDLs specify how much pollutant loading the waterway can accommodate while still attaining water quality standards. TMDLs are to be implemented through both permitting ${ }^{130}$ and planning. ${ }^{131}$ This system should function as a backup approach, assuring attainment of water quality goals where technology-based controls alone are not sufficient. ${ }^{132}$ In practice, however, the TMDL approach has produced limited results.

Little has been accomplished partly because the EPA and the states took so long to begin implementing the TMDL program. ${ }^{133}$ Only in the 1990s—after two decades in which TMDL requirements were almost completely ignored — did a series of environmental lawsuits succeed in jump-starting the program. ${ }^{134}$ But because of the delay—and the complexity, once the process 
actually begins, of drafting and implementing TMDLs - TMDL implementation in thousands of watersheds remains in its early stages. ${ }^{135}$

The terms of the CWA also limit the TMDL program's effectiveness. Section 303(d) requires states to develop water quality standards, identify water bodies that are failing to meet those standards, and develop overall pollution budgets for those water bodies. ${ }^{136}$ The EPA's regulations go a step further, requiring that the TMDL divide the total pollution budget between a "load allocation[]" for non-point sources, a "wasteload allocation[]" for point sources, ${ }^{137}$ and a "margin of safety."138 The CWA also links TMDLs to individual NPDES permits, which, at least in theory, ${ }^{139}$ must contain source-specific effluent limits sufficiently stringent to meet water quality standards. ${ }^{140}$ Finally, the Act requires state planning processes ${ }^{141}$ and allows federal grants to support these planning efforts. ${ }^{142}$ The Act, in short, imposes many obligations and creates a few incentives. But, it does not require that TMDLs include enforceable controls on specific sources. ${ }^{143}$ And if states fail to generate plans, or if their plans propose insufficient controls, the federal government cannot step in and substitute its own plans. ${ }^{144}$ Also, state plans are not federally enforceable, and citizen suits compelling implementation are possible only if authorized by state law. ${ }^{145}$

TMDLs are not completely inconsequential. They usually document causes of impairment, and that information can be useful to regulators or watershed groups interested in pursuing restoration projects. Similarly, if states are motivated to address water quality problems, the TMDL process can provide a method for doing so. ${ }^{146}$ But the historic lack of state interest and 
the inherent weaknesses in the TMDL program leave most TMDLs as documents of, at best, uncertain regulatory importance.

These problems exist for all TMDLs, but the TMDL method is particularly problematic when applied to urban stormwater, where its informational demands are especially difficult to fulfill. Section 303 of the CWA requires states to determine the maximum allowable daily load of each pollutant contributing to water quality impairments. ${ }^{147}$ This requirement presumes that state regulators can determine what each contributing pollutant is and what amount of that particular pollutant (allowing for a margin of error) the water body can assimilate. Often, however, and particularly with urban streams, regulators lack this knowledge. ${ }^{148}$ Urban stream impairment typically arises from a confluence of causes, including loading of multiple pollutants, changes to flow regimes, and habitat loss. ${ }^{149}$ Though scientists are currently trying to isolate the roles of different stressors, their efforts are in the early stages, and separating the combined effects of those stressors and generating allowable loads for each individual pollutant is currently very difficult. A focus on individual pollutants also is likely to ignore key stressors. Flow alterations, though potentially qualifying as "pollution" under the CWA, do not meet the Act's narrower definition of "pollutant," and therefore would not be included in a traditional TMDL. ${ }^{150}$ That does not mean regulators are ignorant about the causes of impairment; they may understand the underlying problem, for most stressors are ultimately traceable to or correlated with the extent of connected impervious cover in the watershed. ${ }^{151}$ But the intermediate links in the causal chain are difficult to discern, and it is on those intermediate links that the traditional TMDL approach focuses. 
In practice, this currently makes traditional, pollutant-by-pollutant TMDLs for urban impaired streams hard to draft and difficult to use. State regulators consistently told me that they have struggled to generate traditional TMDLs for urban impaired streams. ${ }^{152}$ While they were confident that impairment ultimately derived from connected impervious cover, they could not isolate specific intermediate stressors, even after completing extensive stressor analyses. ${ }^{153}$ Nor did they think fulfilling the TMDL requirements was a necessary predicate for restoration efforts. As long as regulators had some rigorous documentation of the root causes of watershed impairment, fulfilling all of the specific TMDL requirements seemed like a waste of time. ${ }^{154}$ Consequently, they found the combination of TMDL requirements and impaired urban streams to be, as one regulator put it, "a square peg and a round hole."155

\section{Other Legal Regimes}

While the CWA is the nation's primary water quality law, it is not the only law that might address urban stormwater problems. Two other candidates — state and local water quality laws and the federal ESA — also seem promising, the former because our federalist system deliberately allows state and local governments to supplement federal efforts, and the latter because impairment of urban streams is, in large part, a problem of lost biodiversity. And in fact, both state water quality laws and the ESA have sometimes contributed to legal responses to urban stream impairment and may do so to a greater extent in the future. But, as with the CWA, neither solution has been or promises to be anything approaching comprehensive. 
a. State and local laws

The CWA clearly allows states to supplement federal requirements. ${ }^{156}$ Local governments also may establish their own water quality controls so long as those controls are not preempted by state law. They also can use their traditional land-use authority to encourage development patterns compatible with water quality protection. In theory, therefore, state and local authorities could compensate for any weakness in the federal system of stormwater regulation.

Some state governments have taken up that invitation. Several states have developed fairly comprehensive design standards for new development projects. ${ }^{157}$ Some have adopted strong landuse controls designed to limit the geographic extent, and therefore water quality impacts, of new development. ${ }^{158}$ Others have developed more focused programs for particularly sensitive regions or for riparian zones. ${ }^{159}$ Even when states have not directly regulated development, they often provide encouragement and technical assistance to local governments considering regulatory programs. ${ }^{160}$ Many local governments have implemented their own programs, some of which are quite sophisticated. ${ }^{161}$ These state and local efforts demonstrate that the federal government is not the only potential source of effective regulation of urban stormwater. Indeed, an optimal regulatory approach probably would include the kinds of development controls instituted by many cities and some states and would allow for other types of state and local innovation. ${ }^{162}$ 
Nevertheless, these effective state and local steps are not the norm. Most states have not established any requirements that exceed the federal baseline. ${ }^{163} \mathrm{~A}$ few states have completely left the field to the federal government, electing not to assume authority over the NPDES program. ${ }^{164}$ Others have taken over NPDES permitting authority but have left that authority largely unexercised. ${ }^{165}$ Many states have actually taken affirmative steps to foreclose the possibility of supplementing the federal regulatory regime. By enacting laws that preclude state administrative agencies from establishing any requirements more strict than those of federal law, those states have effectively made federal requirements the only game in town. ${ }^{166}$ At the local level, the examples of innovative stormwater regulation, while impressive, also remain exceptional; most local governments continue to look to the state or federal government for regulatory direction.

The paucity of state and local initiatives should not be surprising. For years, most state and local governments have been reluctant participants in water quality protection. ${ }^{167}$ Where states have assumed primary implementation authority, progress has often lagged. ${ }^{168}$ Consequently, while some important state and local efforts will likely continue to occur, there is little reason to expect that these initiatives will fill the gaps in the system of federal law.

b. The ESA

The ESA ${ }^{169}$ might also offer a remedy for water quality problems caused by urbanization. The ESA is the nation's primary legal mechanism for protecting biodiversity, and urban water quality 
problems typically lead to biodiversity loss. ${ }^{170}$ But for several reasons, the ESA has not yet been a particularly important source of protection for urban streams.

First, streams in urbanizing areas tend to lose sensitive species quickly, and therefore most urban watersheds do not contain threatened or endangered species. ${ }^{171}$ Second, many of the decisions that lead to urbanization do not involve the federal government. ${ }^{172}$ Consequently, section 7 of the ESA, which precludes federal agencies from taking actions likely to "jeopardize" listed species or adversely modify their critical habitat, often does not apply. ${ }^{173}$ Third, the complex causal links between urbanization and water quality impacts limit the ESA's relevance. Where the decline of a species derives from the cumulative impact of many individual decisions or from uncertain causes, the FWS and NOAA Fisheries have often been reluctant to use section 7 aggressively, instead allowing projects to gradually pile on incremental harms. ${ }^{174}$ The complexities of causation create even greater limits for enforcement of section 9 of the ESA, ${ }^{175}$ which, according to the Supreme Court, prohibits actions only if they proximately cause harm to discrete, identifiable animals. ${ }^{176}$ Perhaps not surprisingly, the ESA has assumed little relevance to urban stream protection, ${ }^{177}$ and plaintiffs have fared poorly in the few cases that sought to force the issue. $^{178}$

Despite these limitations, the ESA has occasionally spurred efforts to protect streams from urbanization and it may do so to a greater extent in the future. Several examples illustrate the ESA's potential effects. In Georgia's Etowah watershed, ESA-based restrictions have spurred the ongoing development of a conservation plan likely to involve the regulation of impervious cover 
runoff. ${ }^{179}$ Developers have faced similar limitations in parts of the Pacific Northwest, where protected salmon inhabit watersheds impacted by suburban expansion. ${ }^{180}$ In Texas, the Edwards Aquifer Authority is considering impervious cover limits as part of its efforts to protect the Edwards Aquifer and the springs and streams it feeds; ${ }^{181}$ those efforts began largely in response to the requirements of the ESA. ${ }^{182}$ While state NPDES program implementation decisions are not subject to ESA section 7, there are some states in which the EPA retains permitting authority, and in those states the EPA may require dischargers seeking stormwater permit coverage to either certify that their projects will not impact listed species or apply for special permits. ${ }^{183}$ If ESA section 7's prohibition on adverse modification of critical habitat continues to emerge from the shadows, ${ }^{184}$ it could lead to significant new permitting requirements, as the relationship between impervious cover and aquatic habitat modification is well-documented. ${ }^{185}$ In short, the ESA, despite some limitations, can be a factor. But it has rarely been centrally important and is never likely to be the primary source of protection.

\section{Underlying Challenges}

As the foregoing discussion indicates, many of the failings of traditional stormwater regulation can be traced to specific provisions of individual laws. But the problems run deeper; for in several ways, urban stormwater presents exactly the kind of environmental challenge our legal system has traditionally struggled to solve. Scholars often argue that environmental laws do at least moderately well at addressing highly visible, readily understandable problems with discrete, identifiable sources. ${ }^{186}$ Untreated toxic effluent from a factory presents a classic example; the 
harm seems palpable and the perpetrator is easy to identify, and for the most part, our legal responses have been effective. But when harms are less visible and mechanisms of degradation are harder to understand, fashioning effective legal remedies has proven quite challenging. The challenges can grow even greater when the environmental problem derives from the cumulative effect of many small decisions rather than from a few discrete actions. ${ }^{187}$

Urban stormwater presents a classic example of those difficulties. The sources of harm, while not impossible to see, are not nearly as apparent as pipes discharging raw effluent or clouds of air pollution. The causal mechanisms are sufficiently hidden and complicated that few people give them much thought (often one of the first tasks confronted by stormwater managers is conducting some very basic public education). ${ }^{188}$ And the underlying cause of harm is the cumulative effect of hundreds of development decisions; ultimately, it is a land use pattern our society has embraced.

Those characteristics suggest that under any legal regime, urban watershed protection would present a substantial challenge. But they also suggest that urban watershed protection could provide valuable lessons. From air quality management to climate change mitigation to habitat protection, environmental managers face similar challenges, particularly as relationships between common development patterns and environmental degradation become increasingly clear. ${ }^{189}$ If regulators and watershed managers can develop more effective approaches to water quality protection, those approaches could inform, and perhaps create synergy with, efforts to address a variety of environmental problems. 


\section{EMERGING APPROACHES}

While traditional legal approaches to urban watershed protection have produced mixed results, this traditional regime is improving. Several of the recent innovations could dramatically change the scope of the NPDES program, the way TMDLs are written, and the form of permitting requirements. In combination, these changes suggest a fundamentally different approach that relies on information technology, collective permitting schemes, and adaptive management to better address the interactions between landscape attributes and watershed ecology. These emerging approaches also are backed by some of the most powerful engines of environmental law implementation: federal enforcement authority and citizen suits. ${ }^{190}$ The emerging approaches will not resolve all of the limitations inherent in older regulatory systems, and they create some new challenges. But even as partial, incremental reforms, they offer intriguing paths toward better water quality.

\section{A. Impervious Cover TMDLs}

One of the main challenges created by the traditional regulatory system is the poor fit between the CWA's TMDL requirements and the problems facing urban streams. Where multiple sources generate multiple pollution problems, all of which synergistically interact to degrade water quality, applying a traditional TMDL-based approach means trying to untangle a Gordian Knot 
of causes and effects. ${ }^{191}$ These challenges are ironic, for the underlying problem —connected impervious cover-is often fairly clear.

To circumvent that problem, regulators in several northeastern states have begun experimenting with proxy approaches, the most prevalent of which is the "impervious cover TMDL." 192 These TMDLs use the desired percentage of connected impervious cover in a watershed (minus a margin of error) as a surrogate for determining maximum allowable pollutant loadings. ${ }^{193}$ In other words, they treat connected impervious cover as a measure of pollutant loading, and they set a targeted cap on connected impervious cover rather than a targeted limit on pollutant loading. Thus, if an impaired stream drains a watershed with 15 percent impervious cover, but research suggests that streams in that state need closer to 11 percent connected impervious cover in order to meet relevant water quality standards, the TMDL might identify a connected impervious cover target somewhere below 9 percent (with the difference between 11 and 9 percent creating the margin of error). ${ }^{194}$ Implementing the TMDL then would involve retrofitting existing development and regulating new construction with the goal of disconnecting or otherwise treating much of the existing impervious cover and any new impervious areas. ${ }^{195}$ The end result, ideally, would be a watershed that functions as though it had only 9 percent impervious cover and a stream that meets water quality standards.

This approach presents several advantages. First, it simplifies the process of TMDL development. Regulators do not need to go through the extremely time-consuming process of developing defensible pollutant load limits for each individual pollutant. ${ }^{196}$ Instead, they may 
rely on land-cover data — which satellite photos and GIS technology make increasingly available — to assess the overall extent of impervious cover "loading."197 Second, this approach should be more responsive to the stressors affecting urban watersheds. A pollutant-by-pollutant TMDL would ignore stressors - for example, excessive or insufficient flows or the loss of riparian habitat - that clearly are important to watershed health, but do not fit within the CWA's definition of "pollutant." 198 An impervious cover TMDL addresses a key underlying source of those stressors and of traditional pollutants and therefore can more comprehensively diagnose a watershed's problems. ${ }^{199}$ Third, this approach can produce better guidance for land use planners. ${ }^{200}$ A conventional TMDL establishes daily mass limits for each relevant pollutant, but planners are generally trained to think about using space, not managing pollutant loads. A limit expressed as a cap on connected impervious cover will be more readily understandable; local planners can intuitively grasp the extent of roof and pavement in their jurisdictions and the influence of local zoning and building requirements on the amount of impervious cover. ${ }^{201}$ An impervious cover TMDL therefore frames the problem so that local governments can start thinking about solutions.

The approach also involves several potential disadvantages. Perhaps most importantly, the legality of impervious cover TMDLs is debatable. The appeal of an impervious cover TMDL is that it avoids the inefficiency and futility of pollutant-by-pollutant daily mass limits. But such limits are exactly what the plain language of the CWA, which demands "total maximum daily loads" for "pollutants," presently ${ }^{202}$ seems to require. ${ }^{203}$ And while no court has evaluated impervious cover TMDLs, decisions addressing other parts of section 303 of the CWA suggest that the judiciary might enforce a literal reading, even where the challenged approach arguably 
serves the Act's underlying goals. ${ }^{204}$ However, that result is by no means certain or clearly justified. For good reasons, judges often defer to agencies that compensate for environmental uncertainties by regulating proxy measures of environmental quality. ${ }^{205}$ And connected impervious cover is a sensible proxy measure; loads of many of the pollutants that stress urban streams do correlate with connected impervious area. ${ }^{206}$ Additionally, as scientific research on urban streams develops, regulators also may be able to refine their understanding of the relevant proxy relationships and might therefore offer stronger legal support for this approach. But for now, the question seems close enough to place impervious cover TMDLs in a legal gray area.

The second potential problem is more practical: there is significant uncertainty about whether achieving the targeted "load" will actually translate into meeting water quality standards. ${ }^{207}$ While using connected impervious cover percentage as a measure of watershed stress has a reasonable scientific basis, at least for small watersheds, data on the effectiveness of mitigation measures still are generally inconclusive. ${ }^{208}$ Regulators therefore may be confident that stream impairment is related to the amount of connected impervious cover in a watershed, but they cannot be sure that the targeted level of retrofits will fix that impairment. Simply setting a connected impervious cover target also is quite different from setting forth a blueprint for a comprehensive, implementable, and enforceable restoration program. Just as traditional TMDLs usually establish overall load and wasteload allocations without allocating cleanup responsibility to each specific source, impervious cover TMDLs generally do not specify who exactly will go about retrofitting their properties, to what standards, and with what methods. ${ }^{209}$ 
Consequently, impervious cover TMDLs provide much better diagnoses than prescriptions. But an improved diagnosis is still useful, and, for streams impaired by urban stormwater, even a diagnosis is more than traditional TMDLs tend to provide. Besides, as subsequent sections discuss, prescriptions can come from other legal sources.

\section{B. Residual Designation Authority}

Another key challenge in protecting urban watersheds is the under-inclusive nature of the NPDES stormwater program. While that program applies to industrial facilities and to most municipal stormwater systems, it traditionally has ignored municipal systems that serve areas that do not meet the default criteria for inclusion in the permitting program. It also has not included private, non-industrial stormwater systems. ${ }^{210}$ Consequently, stormwater discharges from many office parks and big box developments, among other exempted sources, are essentially unregulated. Even for permitted facilities, most traditional permits lack effective mechanisms for addressing the impacts of impervious cover. ${ }^{211}$

The CWA and the EPA's implementing regulations, however, contain a potential—and, considering its historic obscurity, surprisingly powerful—fix for some of these problems. Section 402(p), which defines the stormwater sources subject to and exempt from NPDES regulation, includes a catch-all provision requiring permits for "[a] discharge" that the EPA or a state with delegated NPDES permitting authority "determines . . . contributes to a violation of a water quality standard or is a significant contributor of pollutants to waters of the United States."212 
The EPA's implementing regulations echo that mandate and also allow "any person" to petition the EPA or an NPDES-implementing state to exercise this "residual designation authority."213 Once filed, a petition forces the EPA or the state to make a determination, ${ }^{214}$ and if the EPA or the state determines that the stormwater discharge contributes to water quality violations, permitting is mandatory. ${ }^{215}$ In other words, the Act and its regulations require permitting for any point source that contributes to water quality impairment, whether or not the source is a traditionally-regulated industrial facility, construction site, or municipal stormwater system, and they empower anyone to demand enforcement of that requirement.

Although few people have paid attention to this provision, ${ }^{216}$ its implications are dramatic. Many_perhaps most — urban watersheds violate water quality standards, and ample research demonstrates that the violations derive largely from stormwater discharges, many of them currently unregulated. ${ }^{217}$ Indeed, the few watersheds where the EPA or states have exercised this "residual designation authority" - the upper Charles River in Massachusetts, ${ }^{218}$ Long Creek in Maine, and the area surrounding Burlington, Vermont ${ }^{219}$ — hardly contain unique landscapes. The upper Charles flows through generic, rapidly growing fringe suburbs; Burlington contains a fairly typical transition from urban to rural landscapes; and Long Creek's pattern of offices, malls, and roadways recurs across the nation. ${ }^{220}$ If residual designation authority applies there, it could apply throughout urban, suburban, and exurban America. ${ }^{221}$ Consequently, while the EPA and the states have rarely exercised residual designation authority, the rarity of designations derives from administrative reluctance and the absence - perhaps now ending ${ }^{222}$ —of citizen suits, not from any limiting provision in the law itself. ${ }^{223}$ 
Within those watersheds, residual designation authority could dramatically expand the number of permittees. Most owners of developed land in an impaired watershed will own something - a storm sewer system, a drainage ditch, or even a roof drain - that could be characterized as a point source and that contributes to the waterway's impairment. ${ }^{224}$ In other words, most landowners in impaired watersheds meet the criteria for NPDES coverage. Some (though not all) ${ }^{225}$ of those landowners already are subject to regulation, at least indirectly — their properties may discharge into stormwater systems run by local governments, which in turn are subject to permitting requirements - but residual designation authority raises the possibility that each discharger will be directly and differently regulated. ${ }^{226}$ Under the letter of the law, most urban landowners are now potentially covered, and permitting is only an agency decision—or a petition and, perhaps, a lawsuit- away. ${ }^{227}$

\section{Collective Permitting}

A third set of critiques of existing regulatory approaches argues that even for covered facilities, the permitting requirements are flawed. ${ }^{228}$ The prospect of a massive expansion in the NPDES permitting program heightens the importance of these critiques, for residual designation authority might only direct more effort toward a failing approach implemented by politically constrained and severely underfunded state agencies. ${ }^{229}$ But, after years of advocacy from the EPA and others, a different permitting system is beginning to emerge, one that could mitigate some of the flaws in traditional permitting approaches. ${ }^{230}$ Despite its own complications and limitations, this collective permitting approach offers the prospect of improved regulation. 
Recent developments in the Long Creek watershed, where regulators and permittees are experimenting with a single collective watershed permit, illustrate some of that potential. ${ }^{231}$ Each regulated landowner ${ }^{232}$ in the watershed will choose between buying into a collective permit or seeking individual permit coverage. ${ }^{233}$ Joining the collective permit will mean signing a contract obligating that landowner to pay an annual fee for each acre of impervious cover; ${ }^{234}$ allowing the newly created "Long Creek Watershed Management District"235 access to the landowner's property; and committing the landowner to participation in some collective housekeeping programs. ${ }^{236}$ The funding will allow the management district to design and implement a series of restoration projects, which will range from restoration of riparian habitat to installation of stormwater treatment systems. ${ }^{237}$ Rather than treating each individual parcel as a separate project with a separate budget, managers will implement projects that offer the greatest environmental return for the lowest financial cost, regardless of where those projects are located. ${ }^{238}$ Simultaneously, local land use regulators will heighten controls on new development while relaxing some of the existing controls — minimum parking space requirements, for examplethat previously encouraged development of impervious area. ${ }^{239}$

This approach involves some challenges. The transaction costs are large; regulators and the potential permittees have already spent hundreds of hours developing this conceptual approach and then turning it into a permit and a proposed contract. ${ }^{240}$ Fairness concerns are likely. Regulated landowners question the exclusion of smaller landowners and wonder why local residents, who rely on commercial property values to limit their own tax payments, should not pay. ${ }^{241}$ If the management district works primarily on a few properties, other owners may wonder 
if they were relatively small contributors to the watershed's problems and therefore should have paid less. ${ }^{242}$ And governance will sometimes be difficult. Even a small watershed like Long Creek contains many landowners, and coordinating decisions will be an ongoing challenge. In a watershed with more and smaller landowners, ${ }^{243}$ the transaction costs and potential for conflicts could be significantly higher.

On the other hand, the potential payoff is huge. By allowing watershed managers to focus on the highest-return projects, a collective approach should save permittees a lot of money. ${ }^{244}$ The approach also allows some economies of scale in maintenance projects; a coordinated multilandowner street sweeping program, for example, should cost much less than the aggregate cost of property-by-property individual efforts. ${ }^{245}$ Watershed managers may be able to implement fixes, like riparian habitat restoration or changes to local planning and building codes, that could not occur under a traditional permitting approach. ${ }^{246}$ The collective approach can facilitate coordination not just across property but also jurisdictional boundaries; the permit area will cover multiple towns, thus partially avoiding the common problems created by mismatches between watershed and political boundaries ${ }^{247}$ The project will not be cheap, but over the life of the restoration project these advantages should produce significant cost savings. ${ }^{248}$ Preliminary estimates suggest a 60 percent or greater reduction in costs. ${ }^{249}$

The collective permitting approach also creates a different dynamic among landowners. Instead of placing each permittee in a separate relationship with regulatory authority, the collective permit can create a sense of collective responsibility among permittees. ${ }^{250}$ If several landowners 
neglect to pay into the fund or to allow access to their land, other landowners will need to pay more, and therefore they have a collective incentive to police their fellow permittees. ${ }^{251}$ That dynamic already seems to have had salutary effects in the Long Creek Watershed area. First, the prospect of implementing an approach that could save money inspired members of the business community to work hard to promote the process. ${ }^{252}$ Second, business community members already have engaged and continue to engage in serious conversations about ways to police compliance and to cooperate on restoration. ${ }^{253}$

Finally, while the initial transaction costs may be quite high, the Long Creek process provides an important learning opportunity. ${ }^{254}$ The creation of multiple committees and subcommittees has created forums for dialogue among permittees, and between permittees, towns, and regulators, providing important opportunities for exchanging information. The centralized administrative structure also allows a coordinated monitoring strategy, which should better allow for adaptation as the project proceeds. ${ }^{255}$ Through that monitoring and documentation of procedures and results, the Long Creek effort also could provide a useful example for other watersheds; indeed, multiple participants expressed the hope that the process would create, as one put it, a "replicable model for how to restore an impaired urban watershed." ${ }^{256}$ While in some ways unique, the Long Creek process is in other ways representative of a broader trend. ${ }^{257}$ The EPA, National Research Council panels, and other groups have been advocating "watershed-based permitting" for years, and that advocacy has slowly but increasingly begun to result in real world experiments. ${ }^{258}$ In Georgia's Etowah Watershed, for example, local governments are complying with the ESA by developing a habitat conservation plan in some ways similar to the Long Creek permit. ${ }^{259}$ Other areas have experimented with stormwater utilities, which impose service charges on all entities 
served by a water or wastewater utility and use the revenues to fund stormwater management activities. ${ }^{260}$ The Long Creek process involves more intensive and expensive effort than many of these other projects, ${ }^{261}$ but it still reflects a broader shift toward using innovative permitting approaches to allow watershed-scale remediation.

The benefits of these alternative approaches should not be overstated. Permit compliance still will cost money, and trans action costs may sometimes make these alternative approaches completely untenable. Indeed, there are probably reasons beyond mere inertia why so few watershed permitting processes have developed despite the EPA's sustained promotion of the idea. ${ }^{262}$ But the gradual emergence of these approaches does at least suggest the prospect of a feasible, if not easy, way to cost-effectively integrate more landowners into regulatory processes and thus to begin addressing the impacts of development patterns on water quality.

D. The Combination

In isolation, each of these changes might be ineffectual or even problematic. Impervious cover TMDLs could just identify problems while prescribing only unworkable or overly general cures. ${ }^{263}$ Residual designation authority, while powerful, cannot be invoked without a watershedspecific evidentiary basis. ${ }^{264}$ If widely invoked, it also could overwhelm the NPDES program with a flood of new permittees. Collective watershed-based permitting, standing alone, is an aspiration without a supporting mandate. The whole point of watershed-based permitting is to 
address the full range of stressors affecting a watershed, ${ }^{265}$ but sources without permitting obligations have no incentive to participate.

In combination, however, these approaches move toward an improved regulatory system. The combination is not perfect-in some ways, it leaves excessive discretion, and in others it may be too onerous ${ }^{266}$ - and many other possible measures exist. ${ }^{267}$ But this particular combination is a useful starting point for contemplating more comprehensive reform.

To understand the significance of the shift, one must first reconsider the two traditional regulatory approaches to water pollution control. The NPDES approach treats most permitted facilities like pipes abstracted from environmental context, ${ }^{268}$ with little attention paid to the development patterns on the permittee's property or on adjacent land. While that approach has worked well for discrete pollutant sources amenable to end-of-the-pipe technological controlsin practice, industrial and municipal wastewater discharges - it has accomplished little when landscape patterns are central to pollution problems. ${ }^{269}$ The traditional TMDL/planning approach does consider landscape patterns and environmental context, but its informational demands are very difficult to fulfill, and it is nearly toothless. ${ }^{270}$ Consequently, there is no straightforward way, if regulators use traditional approaches, to address landscape-derived pollution through a manageable and mandatory set of controls. Nor have environmental groups found a way to use citizen suits to force regulators to that endpoint. 
An effective system of controls on landscape-based pollution would be quite differently constructed. It would require regulators to diagnose situations where land use patterns are causing pollution problems; ${ }^{271}$ it would contain a method for linking those diagnoses to permits on specific sources; and it would include some way of writing effective controls into those permits. ${ }^{272}$ The system as a whole would be at least moderately efficient and fair, lest recalcitrant permittees and reluctant regulators stymie implementation. ${ }^{273}$ Its evidentiary demands would not outstrip the capacity of watershed scientists to supply information. ${ }^{274}$ The system would provide opportunities for motivated and innovative people to creatively craft their own solutions. ${ }^{275}$ Because of the substantial uncertainty inherent in water quality planning, it also would create mechanisms for adaptive learning and adjustment. ${ }^{276}$ And the system probably would empower outside parties to compel regulation when regulators are underfunded, politically constrained, or otherwise reluctant to act. ${ }^{277}$ Absent any of those elements, the system would likely prove unworkable.

The new approaches discussed above better conform to that more effective model. Although a TMDL is neither the only nor, perhaps, the best method of arriving at a diagnosis, theTMDL process does at least compel states to figure out why waterways are impaired. ${ }^{278}$ And while fulfilling that obligation normally is difficult when urban stormwater is the key stressor, impervious cover TMDLs create a feasible and relatively efficient method for reaching those diagnoses. TMDLs normally create little compulsion for treatment, but the possibility of residual designation authority significantly changes the equation. If a TMDL identifies aggregate impervious cover levels as underlying causes of water quality impairment, then every landowner with point-source discharges from impervious cover is responsible for contributing to those 
water quality violations, and the evidentiary basis exists for exercising residual designation authority. ${ }^{279}$ The default next step—individualized permitting of every owner of impervious cover in the watershed - would likely be unworkable; but collective permitting offers the prospect of a more collaborative, adaptive, cost-effective, and administratively streamlined approach. In short, impervious cover TMDLs and permitting provisions can provide mandatory steps from diagnosis to enforceable permit, and watershed-based permitting provides a way of making the permitting actually work.

This particular combined system is by no means a perfectly constructed model. By avoiding monitoring, states may avoid even identifying impaired urban streams. ${ }^{280}$ States have no legal obligation — and even have significant legal impediments in the current language of the CWAto prepare impervious cover TMDLs. ${ }^{281}$ The requirements of NPDES permits for residual designation authority sources are not clearly specified by the statute, ${ }^{282}$ and while the EPA and the states could write permits with genuine constraints, they also might imitate the general, hortatory, and largely unenforceable permits widely used for many traditionally-regulated stormwater sources. ${ }^{283}$ Finally, there is an element of a bluff in any state or federal threat to exercise residual designation authority across the landscape. Absent the use of watershed permitting, stormwater utilities, or some other system that creates administrative efficiency and economies of scale, few states or EPA offices could oversee a comprehensive permitting program — particularly for residential watersheds, where regulators might face the distasteful prospect of requiring NPDES permits from individual households ${ }^{284}$ For all these reasons, the combination of approaches represents a set of steps toward a better regulatory system, not a finished product. 


\section{FEDERALIZING THE LANDSCAPE?}

The combination of mechanisms described above may represent a promising shift, but the core insight upon which that shift rests - that protecting water quality often means regulating landscape and development patterns — creates potential conflict with a commonly expressed vision of environmental federalism, in which land use controls should be imposed only at the local or state level. ${ }^{285}$ That conflict could doom the new regulatory model, no matter how sensible it might be, for the traditional view has become powerful and deeply entrenched. This section therefore explains why that common federalism approach, though appealing, could produce unfortunate outcomes in this context.

\section{A. Prevailing Fears}

For decades, Congress has signaled that land use planning is a state or local prerogative. In the 1970s, proposed federal land use planning laws almost all failed to secure passage, and administrative efforts to control pollution through land use regulation met their demise amid vociferous political opposition. ${ }^{286}$ In the CWA, Congress made a show of bowing to those preferences; it asserted its intent "to recognize, preserve, and protect the primary responsibilities and rights of the States . . to plan the development and use . . of land and water resources." 287 While the Act's substantive provisions have imposed limits upon that authority-wetlands 
protections, for example, clearly affect land development—-the idealization of local land use planning has continued to dominate congressional rhetoric. For decades, the preferred battle cry against any expansion in the CWA's scope has been to warn of plots "to give federal bureaucrats authority to make final decisions about local land use." ${ }^{288}$ And, particularly in recent decades, the preferred defense has been to argue, not that federal law has some role to play in land use decisions, but instead that federal law remains safely on the environmental side of the land use/environmental law divide. ${ }^{289}$

The Supreme Court has carried the same tune, sometimes with equal vigor. The Court has insisted that environmental regulation and land use law occupy distinct and separate realms. ${ }^{290} \mathrm{It}$ also has suggested that this distinction holds constitutional significance, with federal regulation that strays too far into the realm of land use being potentially suspect. ${ }^{291}$ Meanwhile, judicial defenders of federal water quality protection, much like the congressional advocates of water quality legislation, sometimes appear to concede the inappropriateness of having federal regulation affect land uses. They seem to prefer to assert that the CWA appropriately sticks to environmental protection. ${ }^{292}$ The Court has been far from consistent in asserting this distinction, and justices have sometimes suggested that Congress may trump local land use authority wherever the Commerce Clause permits. ${ }^{293}$ These federalist intuitions also have yet to coalesce into any sort of discrete legal standard and may never do so. ${ }^{294}$ But the overall message—albeit a mixed one - is that courts may question any regulatory initiative that extends federal law any further into the realm of land use planning. 
Some of this legislative and judicial skepticism clearly derives from an anti-regulatory agenda, and many statements suggest at least as much frustration with the substance of regulatory programs as with their source. ${ }^{295}$ But the rhetoric also foreshadows a genuine clash between the emerging controls on landscape-derived water pollution and a prominent vision of federalism, in which liberty, responsive government, civic engagement, and experimentation all are promoted by cabining federal authority in limited and discrete spheres ${ }^{296}$ — land use regulation not among them. It also tracks broader themes voiced in academic literature, which often portray federal environmental regulation as blunt, inefficient, rigid, and litigious, ${ }^{297}$ and identifies local governance as the desirable ideal. ${ }^{298}$ Most academic critiques are more nuanced than the political broadsides and often support different fixes; many of the most prominent academic critics of traditional federal environmental regulation prefer a shift toward incentive-based regulation rather than systematic devolution to state or local control. ${ }^{299}$ But the aggregate impression one could easily take from these political, judicial, and academic dialogues is that any extension of the CWA's reach, or the reach of any other federal environmental statute, into land use planning will be the antithesis of good-government reform. An extension spurred by litigation would be even worse. $^{300}$

All of this may sound compelling in theory. But actual practice provides an important test. And while one case study obviously cannot prove a general point, a return to Long Creek, where residual designation authority already has dramatically extended the CWA's reach, can shed some light on the theoretical case against federal expansion. To date, what has actually happened is quite different from what prevailing federalist theory would predict. Instead of producing a disaster, the intervention of federal law has actually served as a spur to innovative governance. 


\section{B. Practical Realities}

Until the latter part of the last decade, federal environmental law played little role in the development of the Long Creek watershed. Land use development occurred primarily at the local level. ${ }^{301}$ Nor was there much public involvement in those planning decisions. South Portland in $\operatorname{particular}^{302}$ was a developer's town, a place where local government courted businesses and citizen involvement in planning decisions was minimal. ${ }^{303}$ What emerged in the Long Creek watershed was neither a distinctive land use pattern nor a particularly hospitable one. A visitor dropped down amid the watershed's malls and offices would have no clue where in America he was - an ironic result in a state that takes pride in achieving a distinctive quality of place. ${ }^{304}$

State and local governments did at times express concerns about stormwater runoff and water quality, but their concerns produced few results. In the 1970s and 1980s, as development was booming, regulators imposed some controls designed to limit flooding. ${ }^{305}$ Later, the Maine Department of Environmental Protection (the "Maine DEP") used federal funding to conduct a comparative study assessing differences between Long Creek and a neighboring, mostly undeveloped watershed. The study demonstrated that Long Creek had markedly reduced biodiversity and increased pollutant levels. ${ }^{306}$ But, at least initially, regulatory controls did not

follow. ${ }^{307}$ Local government representatives were also concerned about the watershed's land use pattern, but had not figured out how to induce change. ${ }^{308}$ 
A few years after the studies, however, circumstances shifted dramatically. In 2007, the City of South Portland, with the support of other towns and the Maine DEP, initiated a collaborative planning process to address water quality problems in Long Creek. ${ }^{309}$ Using federal grant money, the participants hired a professional facilitator who drew in additional participants, and they secured sustained involvement from the local chamber of commerce and from many of the watershed's largest public and private landowners. ${ }^{310}$ Over several years, and through many meetings, they developed the collective permitting approach described above. As this article goes to press, 93 percent of the eligible landowners have elected to participate in the collective permit, and the management district is beginning to implement restoration projects. ${ }^{311}$

Participants consistently describe the process as something special, a demonstration of the positive potential of local collaboration. The mutual respect among the participants is striking. In interviews, they consistently praised fellow participants, including people who might normally have been their adversaries. ${ }^{312}$ While collaborative environmental management may sometimes produce warm feelings but few results, here the participants' enthusiasm seems justified. The participants' watershed-based permitting approach is genuinely innovative, could produce real environmental benefits at significant cost savings, and could provide a template for restoration efforts elsewhere in the state or nation. And even if the effort does not succeed in cost-effectively meeting restoration targets, the process at the very least will provide important information for a belatedly growing public debate on how to address pervasive gaps between legal water quality standards and actual environmental conditions. 
All those positive outcomes did not occur, however, because of cabined federal authority or because of the absence of traditional legal levers. The EPA was minimally involved in the discussions, other than to provide the grant funding that made them possible. ${ }^{313}$ But the participants generally concurred - some grudgingly, others emphatically - that few positive outcomes would have occurred had the Conservation Law Foundation ("CLF"), a regional environmental group, not threatened to invoke federal law by filing a residual designation authority petition. ${ }^{314}$ Similarly, most participants agreed that the CLF's decision to actually file the petition helped focus the collaborators' efforts. ${ }^{315}$ That decision ruffled some feathers, but it strengthened regulators' hands and created a sense of urgency for the potential permittees, providing an incentive for everyone to stay at the table. ${ }^{316}$ One anecdote summarizes the importance of that federal lever: a city councilmember told me that at a watershed tour early in the process, he had encouraged a CLF attorney to file suit, on the theory that it would take a legal obligation to motivate local action. ${ }^{317}$

The Long Creek process does support some aspects of the traditional federalist vision described above. It shows that real environmental management expertise and creative potential exist at local levels; ${ }^{318}$ that some private companies can and will constructively embrace environmental restoration efforts; ${ }^{319}$ and that collaboration can produce not just a satisfying process but also substantive results. ${ }^{320}$ The Long Creek story also provides reminders that even if legal threats may sometimes be necessary prerequisites for successful collaboration, they are rarely sufficient; by all accounts, the expertise, patience, and diplomacy of many participants, including the same attorneys who were creating the legal threat, were essential to the group's success. ${ }^{321}$ 
Obviously, this story does not, by itself, prove a general point. Long Creek is just one watershed, and in some ways a distinctive one. ${ }^{322}$ But what happened in Long Creek is consistent with a broader trend identified throughout much of the literature on watershed protection and environmental governance. Federal law, sometimes invoked by environmental groups threatening or actually filing lawsuits, has often triggered, not squelched, local creativity. Innovative restoration processes on the Sacramento and San Joaquin Rivers. ${ }^{323}$ the Columbia River, ${ }^{324}$ the Platte, ${ }^{325}$ the Everglades, ${ }^{326}$ and the Kennebec River, ${ }^{327}$ to provide just a few examples, all started under the pressure of federal law and often at least partially in response to actual or threatened litigation. State and local governments do not always need a federal push to act, of course; sometimes they pursue innovative approaches despite federal inactivity or even opposition. ${ }^{328}$ But the stories are legion, particularly in the field of water law, of federal law's absence (or non-enforcement) producing not innovation but nearly homogenous inaction. ${ }^{329}$

That trend suggests that the standard federalism rhetoric is missing something important. A core premise of that rhetoric is that federal disengagement correlates with local involvement and innovation. ${ }^{330}$ No doubt that is sometimes true. But sometimes federal disengagement provides space for different national-scale actors - in Long Creek, for example, the national chains that occupy much of the watershed - to impose standardized development patterns, or for local businesses, city governments, and highway agencies to copy cookie-cutter approaches developed elsewhere, notwithstanding the preferences of the local electorate. Federal law, in other words, is not the only potential source of uniformity, and the absence of federal law does not necessarily mean robust local engagement. And if federal law applies, as it often does, while creating opportunities for local involvement, ${ }^{331}$ it may inspire and empower local individuals or groups to 
create diversity and innovation, which are exactly the things a federalist system is supposed to promote. $^{332}$

The Long Creek experience thus demonstrates, at the very least, that the standard federalist rhetoric is not always right. And it provides a strong data point in support of alternative views emerging in recent academic work. Whether termed "adaptive federalism," "modular regulation," or something else, these alternative conceptual approaches emphasize overlapping authority as a precondition for intergovernmental dialogue and innovation. ${ }^{333}$ These authors suggest that creativity and engagement thrive when we empower different levels of government to work together and to work with environmental groups and private sector businesses, subject to some background constraints supplied by federal law. ${ }^{334}$ Their theories also acknowledge the reality that environmental governance and environmental politics are inherently multijurisdictional ${ }^{335}$ Many environmental problems correspond poorly to more localized political boundaries, ${ }^{336}$ and, contrary to conventional federalist rhetoric suggesting all problems should be resolved as locally as possible, the American public widely supports environmental initiatives from multiple layers of governance. ${ }^{337}$ These alternative conceptions of federalism thus provide theoretical counterpoints to the prevalent view that federalism functions best as a system of separating boundaries. They argue instead that a system of integrated responsibilities and interpenetrated levers for action is both pragmatically and democratically preferable. The Long Creek process provides empirical evidence of the merit of those alternative conceptions of federalism. 


\section{TRIAGING WATERSHEDS}

While the Long Creek process was unfolding, another Maine city was beginning its own urban stream restoration project. Birch Stream, which flows through Bangor, Maine, is not a prominent community resource. An airport and a mall cover much of the watershed, and Birch Stream emerges from culverts only half a mile from its confluence with a larger stream. ${ }^{338}$ A few residences occupy the lower watershed, but no public walkways follow the stream's banks. ${ }^{339}$ A longtime local water manager told me that he had never known the waterway was anything more than a drainage ditch. ${ }^{340}$ But in the eyes of the law, Birch Stream is just as important as a longer, more accessible urban stream, and its failure to attain water quality standards is legally problematic. The State of Maine has prepared a TMDL for the watershed, ${ }^{341}$ and the City of Bangor already has spent approximately five million dollars on restoration work, with more to come. $^{342}$

Birch Stream highlights different questions about urban watersheds - questions that assume greater urgency with the emergence of legal tools potentially capable of compelling restoration of nearly every urban, suburban, and exurban stream. Is rehabilitation of urban watersheds really worth the costs? Even if it is, at least in the aggregate, should some watersheds enjoy higher priority than others? And even if prioritization would be good policy, is it legal? If not, how can legal reforms allow triage without creating a slippery slope toward complete inaction? These are all thorny questions, and this section begins addressing the answers. 


\section{A. The Case for Prioritization}

In recent years, a variety of commentators, including some who are strongly committed to water quality improvement, have argued against comprehensive and complete restoration of urban watersheds. For example, the Center for Watershed Protection has urged abandoning full restoration as a goal for urban watersheds, and the organization's founder has argued that water quality expectations should be inversely proportional to the degree of watershed urbanization. ${ }^{343}$ A recent National Research Council ("NRC”) study of urban stormwater management echoed that suggestion. ${ }^{344}$ Somewhat similarly, several previous reports by the NRC and others have argued that water quality restoration efforts should be combined with continuous reassessment of restoration goals, ${ }^{345}$ and the EPA has encouraged "use attainability analyses," which assess the feasibility of actually attaining water quality standards. ${ }^{346}$ These recommendations all reflect a widely shared perception that current water quality goals are often unrealistic and counterproductive and therefore ought to be widely changed. ${ }^{347}$

There are multiple justifications for this view. First, demanding standards, while symbolically appealing, may be excessively expensive. ${ }^{348}$ Complete restoration of every urbanized watershed is almost certainly impossible, for even with the best treatment systems, an urban landscape cannot function like an undeveloped forest. ${ }^{349}$ Even achieving more modest restoration goals is much more costly than preventing degradation in a relatively healthy watershed, for retrofitting development usually costs more than building in a particular way in the first instance ${ }^{.350}$ Many urban stream specialists therefore think that the best ratios of environmental gain to financial cost 
could be realized by focusing on watersheds at or beyond the suburban fringe. ${ }^{351}$ In highly urbanized areas, by contrast, the environmental benefits of restoration may fall short—far short, in the view of some observers - of justifying the multi-million dollar costs, and lower standards might be more consistent with societal goals. ${ }^{352}$

Many commentators also worry that focusing on the most heavily urbanized watersheds could be environmentally counterproductive. ${ }^{353}$ Recognizing the links between impervious cover density and water quality, cities and states might preclude additional development within alreadyurbanized watersheds and impose large lot size requirements or other density controls in less developed areas. ${ }^{354}$ Some localities already have tried the latter approach, sometimes voluntarily and, in the Pacific Northwest, sometimes under pressure from fisheries regulators. ${ }^{355}$ But if these restrictions just spread development, the aggregate effect will be more sprawl, leading to greater aggregate water quality impacts and also to increased habitat loss, road construction, vehicle miles traveled, and air pollution emissions, among other problems. ${ }^{356}$ Similarly, even if local governments impose no zoning constraints, the economic cost of urban stream restoration requirements might discourage infill development ${ }^{357}$ and create a sort of "brownsheds"358 problem, with environmental liabilities limiting urban redevelopment and pushing construction to the undeveloped urban fringe. That outcome would be ironic, for local governments might attain larger environmental benefits by concentrating their planning and regulatory efforts upon such undeveloped areas. Indeed, many of the standard mechanisms for protecting less developed watersheds - limiting road length and size, preserving trees, and clustering development to protect open space, for example - could complement efforts to address other adverse consequences of urbanization. $^{359}$ 
The third primary argument in favor of systemized prioritization is that, as a practical matter, some prioritization is inevitable. Even if laws ostensibly require restoration of every urban stream, local, state, and federal governments will be hard-pressed to find the time, money, and political capital to fulfill those mandates ${ }^{360}$ Many watershed restoration efforts rely on federal grant funding, but there are not sufficient funds for every stream, and every grant for urban stream restoration is unavailable for other water quality initiatives. ${ }^{361}$ Permitting requirements theoretically could transfer much of the financial burden to regulated permittees. But private resources are not infinite, and with tight state and federal budgets, the additional resources and personnel necessary to even administer expanded permitting programs will not be readily forthcoming, even if the political will to regulate is. Consequently, state and local governments will pick their spots, no matter what the law ostensibly requires. Environmental groups theoretically could spur pervasive regulation through litigation, but that too is unlikely; such groups generally can afford to address only a subset of their priorities. ${ }^{362}$ Indeed, given their limited resources, both government agencies and environmental groups might well be inclined to focus on the most degraded watersheds. ${ }^{363}$ Despite all the advantages of preventive work, sometimes only a present crisis can motivate a response — or provide a sufficiently clear basis for a legal action. ${ }^{364}$ Consequently, if some prioritization inevitably will occur, perhaps it ought to occur systematically rather than through the uncoordinated, opportunistic, and largely reactive decisions of dozens of underfunded and overstretched entities, all struggling to implement a sometimes symbolic and occasionally overly stringent legal mandate.

\section{B. The Case Against Prioritization}


While a triage approach may be practically unavoidable, it will create its own problems. The issues are partly legal; despite the arguments in its favor, triaging does not fit well with the existing regulatory scheme. That regulatory structure could change, but there are also powerful practical arguments against a more flexible approach.

\section{Legal Constraints}

Much of the literature on urban watersheds suggests that the EPA and the states could readily start downgrading water quality standards for urban streams. ${ }^{365}$ And the CWA does seem to provide several mechanisms. Setting water quality standards is a state responsibility, though the EPA holds approval authority, and states do establish more protective standards for some waterways than for others. ${ }^{366}$ States also must update their water quality standards every three years, and that process theoretically should allow for continuing adjustment. ${ }^{367}$ States may downgrade water quality standards if they can demonstrate, through use attainability analyses, that current standards cannot be fulfilled. ${ }^{368}$ Finally, even where standards themselves cannot be revised, states are obligated to create "priority ranking(s)" for impaired water bodies. ${ }^{369} \mathrm{In}$ combination, these provisions suggest substantial flexibility.

In practice, however, standards typically are ambitious and difficult to change. The CWA's initial deadlines for setting standards were quite short, ${ }^{370}$ and the EPA pressed the states to adopt 
standards consistent with the Act's "interim" goal of making waters fishable and swimmable unless the states could affirmatively demonstrate that those goals were unattainable. ${ }^{371}$ Many states, lacking time to perform comprehensive studies (or, perhaps, lacking willingness to admit to modest goals), elected to base all of their standards on those interim goals. ${ }^{372}$ Consequently, many states' standards initially demanded fairly pristine water quality across the map, even in urban areas where people would readily accept substantial alteration of terrestrial ecosystems. ${ }^{373}$ These ambitious goals were not happenstance; spurring major improvements in water quality, even at great cost, was the whole point of the CWA. ${ }^{374}$ And most states do have tiered expectations, not uniform, blanket standards. ${ }^{375}$ But, as years of subsequent research have revealed, even the lower-tier standards may be difficult to reconcile with the hydrologic realities of traditional urban development, ${ }^{376}$ and the challenges have only grown as urbanization has expanded across the American landscape. ${ }^{377}$

While the tension between ambitious water quality standards and urbanization patterns has become increasingly clear, revising those standards to accommodate urban development is not easy. In accordance with federal anti-degradation requirements, ${ }^{378}$ states may lower water quality standards only if a use attainability analysis demonstrates that the water body cannot attain quality levels sufficient to support a water body's designated "uses." ${ }^{379}$ For several reasons, such demonstrations are difficult to make. First, the EPA does not allow states to abandon a designated use that is also an "existing use." "380 That might not seem constraining, for the core problem in many urban areas is that streams currently fail to support their designated uses, but the EPA defines an existing use as any use that existed at any time after November $28,1975^{381}$ Consequently, for many areas that urbanized after 1975 - which includes much of suburban 
America - a downgrade is not legally possible. Second, while the EPA's regulations allow use attainability analyses to consider the social and economic costs of restoration, those costs cannot be the justification for a downgrade if technology-based controls on point sources, including sources designated under residual designation authority, could still lead to attainment. ${ }^{382}$ Third, the EPA generally adheres to a presumption of attainability, and the burden of proof thus lies with the party arguing that a use cannot be attained. ${ }^{383}$ Finally, despite the EPA's recent promotion of use attainability analyses, ${ }^{384}$ guidelines for preparing those analyses are still sparse. ${ }^{385}$ Successful use attainability analyses therefore remain rare, particularly for streams in urbanizing areas. ${ }^{386}$

States often still do try to adjust their goals for impaired water bodies. They have attempted to delay promulgation of standards until use attainability analyses could be completed, ${ }^{387}$ to "interpret" water quality standards in ways that effectively revise them, ${ }^{388}$ or to submit water quality standards that fall short of statutory requirements. ${ }^{389}$ Through sparse monitoring or creative definition of water quality standards, states also can avoid even identifying water quality problems. ${ }^{390}$ And, as Houck and others have thoroughly documented, states' efforts to respond to the water quality violations they do detect have been uneven at best, particularly outside of the traditional NPDES permitting program. ${ }^{391}$ The EPA has sometimes intervened to address those practices, ${ }^{392}$ but not always, and often only when compelled by court order. ${ }^{393}$ In short, legal limits on flexibility do not mean the practical absence of flexibility, and even with the emergence of a powerful legal lever like residual designation authority, rigidly consistent adherence to strict water quality standards is unlikely. ${ }^{394}$ Nevertheless, with legal paths to downgrades difficult to follow, if not actually blocked, and illegal paths potentially precluded by EPA oversight or 
judicial enforcement, a major shift in water quality standards for urban streams seems possible only through widespread and uncorrected disregard for existing law.

\section{Information and Incentives}

While existing law may limit revisions to urban water quality standards, that alone is not sufficient reason to reject the possibility of such revisions. Laws can change. And in this context, where many of the key legal requirements come from administrative regulations and interpretive documents, legal change could occur more readily than if major statutory revisions were

necessary. ${ }^{395}$ But there are reasons why the inflexibility of current law may be quite valuable.

Understanding the potential value of inflexibility requires considering the perils a more flexible, triage-based approach would create. To work well, triage requires adequate information, a disinterested decision-maker, a process for making comparative decisions, and an accepted methodology for drawing distinctions. Absent information, triage can turn to guesswork. Without a comparative process and an accepted decision-making methodology, decisions can easily become haphazard and inconsistent. And without a disinterested decision-maker, a triaging process obviously will be tainted by bias. In short, in the absence of fairly ideal conditions, a prioritization system could turn incoherent or could easily degenerate into a process for developing watershed-by-watershed excuses for doing nothing. Even worse, with the threat of expensive watershed restoration requirements gone, state and local governments might lose their primary incentive to protect watersheds that are stillhealthy, or that are only moderately 
degraded. ${ }^{396}$ Unfortunately, in the context of urban watershed management, all of these necessary elements may often be absent.

The first potential practical problem with a prioritization approach is the likely pervasiveness of information gaps. An informed decision about urban watershed restoration would likely require consideration of the ecosystem services provided by the stream and its surrounding habitat (both within and downstream of the watershed). Decision makers also ought to consider the values current and future people, both within and outside of the adjacent community, would place upon those ecosystem services, the recreational value of the stream, and the economic and political feasibility of protecting or restoring the watershed. Ideally, managers also would be able to assign some weight to the importance of an ethical commitment to environmental integrity, however such integrity might be defined for an urban setting. ${ }^{397}$ And they might also want to consider the economic incentives and political signals that watershed protection or restoration would create. Would a robust and ex pensive restoration mandate push development to other locales or, perhaps, induce other locales to better regulate development? Both reactions seem plausible - and there is some evidence that Long Creek already is spurring the latter reaction $^{398}$ - and the relative likelihood of the two reactions has major implications for policy choices.

Unfortunately, much of this information is presently unavailable. ${ }^{399}$ Managers may have little idea what an urban watershed means to the surrounding community, and people in the community may not understand the recreational benefits or ecosystem services the watershed 
provides—or could provide if somehow restored. ${ }^{400}$ Engineers and watershed scientists may generally understand that restoration of highly urbanized watersheds costs more than protection of sparsely settled areas, but budgeting urban stream restoration projects remains difficult, particularly with substantial remaining uncertainties about the effectiveness of treatment methods. ${ }^{401}$ Likewise, economists know that watershed health can bring economic value, ${ }^{402}$ but research on the economic significance of healthy urban streams is minimal. ${ }^{403}$ One could finesse these information gaps by using a crude triaging approach that targets protection efforts to the least urbanized areas, where environmental recovery is likely to come at the lowest financial cost. ${ }^{404}$ But that approach involves its own potential paradox: urban areas are usually accessible to more people, and there is obvious logic and, potentially, environmental justice behind restoring natural environments in the places where large numbers of people actually live, work, and recreate. ${ }^{405}$ To be done well, then, triage may require more information than most watershed managers can readily gather.

For a variety of reasons, unbiased decision-makers also may be the exception rather than the norm. Collective action and public choice theories provide a partial explanation; stream restoration often serves diffuse interests while creating more focused costs, and one might reasonably expect those who bear the costs to wield disproportionate influence in the triaging process. ${ }^{406}$ That disproportionate influence is particularly probable if, as is often the case, most people are unaware of the ecosystem services that a stream provides, while those bearing the impacts are especially accustomed to engaging regulatory processes. ${ }^{407}$ In many state and local government offices, developers, large companies, and other major landowners are a familiar presence. ${ }^{408}$ To the extent that urban watershed impairment creates problems for downstream 
receiving waters, a collective action problem impedes restoration; a community will likely realize all of the costs of limiting the downstream migration of pollution, but the benefits may be harder to discern unless other communities pursue similar restoration projects. ${ }^{409}$ Finally, psychological tendencies like the endowment effect and the normal human tendency toward hyperbolic discounting may distort valuation of restored streams. ${ }^{410}$ It is easy to undervalue a healthy urban stream if you have become accustomed to degradation and if you do not expect to see recovery until a five- or ten-year restoration process is complete. ${ }^{411}$ All of these tendencies may help explain why states and local governments have often been so reluctant to engage in urban watershed protection - and why Congress and the EPA have traditionally favored legal approaches that deny much of the flexibility that systematic triaging would require.

Counterbalancing such disproportionate interests and tendencies toward inertia may require clear, simple, and facially inflexible rules. ${ }^{412}$

Finally, existing law creates few opportunities for comparative decision-making. In multiple ways, the CWA encourages independent decision-making processes for each watershed. Each impaired waterway gets its own TMDL. ${ }^{413}$ The EPA's use attainability analysis regulations anticipate a watershed-by-watershed approach. ${ }^{414}$ Watershed-based permitting, as envisioned by the EPA, provides a mechanism for allocating effort within a watershed, not between watersheds. ${ }^{415}$ The EPA must make some comparative judgments when allocating grant funding, and comparative judgments about different sub-watersheds are unavoidable if regulators are focusing on a large watershed with multiple tributaries. But existing law otherwise does not create processes for weighing the value of restoration efforts in watershed A against efforts in watersheds B and C. Nor does it provide a mechanism for downgrading expectations in 
watershed $\mathrm{A}$ if work in watersheds $\mathrm{B}$ and $\mathrm{C}$ would provide greater value. Absent a mechanism for making such comparative choices, prioritization could occur through a series of poorly informed, ad hoc decisions.

\section{Finding Balance}

The emerging legal mechanisms for stronger protection of urban watersheds create a quandary. Mandating intensive restoration of every impaired watershed in the country, as now seems legally possible, is unrealistically ambitious; the aggregate financial costs of restoring literally thousands of watersheds would be astronomical and the environmental side effects might be serious. But there are reasons to be skeptical about giving state or local governments' broad discretion to pick their spots. Indeed, in practice, state and local governments typically have held such discretion, and the common result has been inattention to urban water quality, even when some proactive attention might have produced great environmental benefit at little or no cost.

The key question, then, is whether there is some way to introduce greater flexibility into the legal system without losing the positive incentives that stringent mandates create. My tentative answer - a hypothesis, at this stage ${ }^{416}$ — is that such a mechanism can be developed. While its creation likely would require new regulations and administrative guidance, the changes need not be drastic, and the overlying statutory structure could remain intact. ${ }^{417}$ The mechanism would involve a basic premise: the EPA would allow a state to downgrade water quality standards for small watersheds in highly developed areas if the state could show (1) that present-day uses ${ }^{418}$ of 
the urban watersheds would not be impaired; (2) that the downgrades would not contribute individually or cumulatively to violations of water quality standards in larger receiving waters; ${ }^{419}$ (3) that the social cost of fully restoring the urban watershed clearly would outweigh the social value; (4) that affected communities had ample opportunity to participate in the downgrade decisions; and, crucially, (5) that the downgrades would be balanced by an overall program to address landscape-based impacts on water quality across the state. That program would need to include more than just vague assurances and hortatory commitments. Instead, the state would need to demonstrate the existence of meaningful incentives and enforceable regulatory controls sufficient to ensure low-impact development patterns, both on a site-specific and a watershed scale; the existence of a monitoring program robust enough to verify the effectiveness of the regulatory program; and the presence of enforceable contingency measures or other penalties should the monitoring program detect water quality deterioration. The state would need to show, in other words, that it was genuinely triaging — that selected urban watersheds were held to a lower standard because treatment elsewhere would do greater good and, importantly, would actually occur.

Fleshing out this proposal and assessing its viability will require additional research. The key overarching question is whether restoration efforts in some watersheds are in fact more valuable than efforts in others. If not, triaging is not nearly as essential as the literature currently suggests. To answer that question, in turn, requires better understanding of the social and environmental values provided by different watersheds; managers and researchers still do not know enough about the ways in which communities value small watersheds. ${ }^{420}$ Nor do we know enough about how those values would evolve if urban watershed restoration became a subject of more 
pervasive governmental initiative and public debate. ${ }^{421}$ Similarly, while watershed scientists and engineers know that exurban and rural watersheds cost less to protect, no accepted methodology exists for weighing those cost savings against the value of restoring watersheds in densely populated areas where, presumably, restoration will benefit more people. ${ }^{422}$ It seems probable that, even within similarly urbanized areas, some watersheds will be easier to restore than others. But because there are few case studies of urban watershed restoration, scientists and engineers cannot readily discern which urban watersheds could be restored more easily and what degree of restoration one might reasonably expect. ${ }^{423}$ Finally, few studies have rigorously evaluated the economic and regulatory incentives created by a legal mandate for urban watershed restoration. ${ }^{424}$ If that mandate primarily deters infill development, triaging is crucially important. But if a few expensive cleanups inspire governments or developers elsewhere to prevent degradation, inflexibility may be well worth its costs.

The nature of these questions also has implications for the future of urban watershed research. None of these questions is purely legal or ecological; indeed, none fits neatly within the bounds of any particular discipline. The degradation of urban streams instead creates an unavoidably interdisciplinary problem, one that demands expertise not just from physical scientists but also from social scientists, engineers, economists, and lawyers. With the combination of a developing scientific consensus on the effects of impervious cover and emerging legal levers capable of translating that consensus into mandatory obligations, the problem is now urgent.

\section{CONCLUSION}


Two hours' drive south of Long Creek, another watershed stands at the cusp of this transformation of the law of urban waterways. The Charles River, unlike Birch Stream or even Long Creek, is not the least bit obscure. It is a short river — only eighty miles in length — and its watershed, at approximately 308 square miles, is not huge. ${ }^{425}$ But nearly a million people live in that watershed. ${ }^{426}$ They, and the region's many visitors, put the river to heavy use: approximately 20,000 people recreate on or along the river on an average day. ${ }^{427}$ The river also is an important cultural landmark; among other things, it was the start of Paul Revere's ride, it is the site of one of the world's largest rowing regattas, and it remains the distinguishing feature of the Boston landscape. Without exaggeration, the EPA has referred to it as "one of the most historically and culturally significant rivers in the United States. $" 428$

The Charles is much cleaner than it once was. For over a century, its pollution was legendary, the stuff of pop songs and presidential campaign rhetoric. ${ }^{429}$ Years of intensive effort - much of it devoted to the traditional CWA priorities of controlling industrial discharges and constructing sewage treatment plants — have gone a long way toward improving the river's water quality. ${ }^{430}$ But the Charles still falls well short of attaining water-quality standards, ${ }^{431}$ and, just as in Long Creek and in many other urban watersheds, a key cause is the impervious cover associated with urbanization of the watershed. In 2008, the EPA invoked residual designation authority and declared its intent to require permits for all landowners with an acre or more of impervious cover. $^{432}$ The EPA started small; the initial declaration applies only to four towns in the upper watershed. ${ }^{433}$ But there is no legal or scientific reason why the designation could not be expanded to cover the entire watershed. ${ }^{434}$ 
This nascent regulatory initiative highlights the potential reach of the legal developments described in this Article. Though pioneered in small, little-known watersheds, the new approaches are grounded in laws that could apply across the urbanized landscape; the development patterns of the Charles River watershed are similar to those across much of America. The Charles River efforts also illustrate the gravity of the shift. While restoring Long Creek will be no small feat, the restoration of a nearly million-person watershed will be an extraordinary task. But the Charles River restoration efforts also illustrate the potential benefits and the costs of continued indifference to the water quality impacts of development. Ignorance of those impacts contributed to chronic water quality violations, many of which might have been cheaply ameliorated through some proactive planning, in one of the nation's most important urban waterways. Addressing them, both in the Charles and in many other watersheds, still could accelerate the already-ongoing rediscovery of urban watersheds, and, more generally, of the potential value of urban environments. ${ }^{435}$

This Article has argued that the emerging framework for addressing those impacts should be reformed in several ways. But even with their flaws, the emergent approaches can start redressing environmental problems that have long seemed intractable, and can provide an impetus and a starting point for developing an improved legal regime. 
Acknowledgements

I thank Tony Arnold, Colin Apse, Eric Biber, Curtis Bohlen, Karen Cappiella, Dan Esty, David Hart, Rita Heimes, Steve Hinchman, Bjorn Lake, Sarah Schindler, Jenny Wriggins, and participants at the Stanford-Yale Junior Faculty Workshop for comments on earlier drafts, and Peter Glaser, Meghan Ogren, Reeve Wood, Randa Capponi, and Shannon Carroll for excellent research assistance. Research for this article was supported by National Science Foundation award EPS-0904155 to Maine EPSCoR at the University of Maine and by the University of Maine School of Law. I also thank the staff members of the University of Colorado Law Review for their excellent work. 
Footnotes

1. See Long Creek Watershed, LONG CREEK RESTORATION PROJECT, http://www.restorelongcreek.org/maps/Long_Creek_Watershed.pdf (last visited Oct. 7, 2009).

2. See West End Trails Master Plan, S. PORTLAND LAND TRUST (Nov. 2008), http://www.splandtrust.com/South_Portland_Land_Trust/West_End_Master_Plan_files/MP.pdf.

3. Interview with Patrick Cloutier, Director, S. Portland Water Res. Dep't, in S. Portland, Me. (June 18, 2009).

4. CASCO BAY ESTUARY P'SHIP, STATE OF THE BAY 2005, at 4 (2005).

5. See U.S. ENVTL. PROT. AGENCY, EPA/600/R06/065F, CAUSAL ANALYSIS OF BIOLOGICAL IMPAIRMENT IN LONG CREEK: A SANDY-BOTTOMED STREAM IN COASTAL SOUTHERN MAINE (2007); JEFFREY T. VARRICCHIONE, ME. DEP'T OF ENVTL. PROT., A BIOLOGICAL, PHYSICAL, AND CHEMICAL ASSESSMENT OF TWO URBAN STREAMS IN SOUTHERN MAINE: LONG CREEK \& RED BROOK (2002); FB ENVTL. ASSOC., INC., LONG CREEK WATERSHED MANAGEMENT PLAN 1-2 (2009).

6. U.S. ENVTL. PROT. AGENCY, PRELIMINARY RESIDUAL DESIGNATION PURSUANT TO CLEAN WATER ACT 4 (2008) [hereinafter LONG CREEK PRELIMINARY RESIDUAL DESIGNATION].

7. See id. at 4-9. I use the phrase "water quality" in the same broad sense as the CWA. See 33 U.S.C. § 1251(a) (2006) (declaring that the goal of the Act "is to restore and maintain the chemical, physical, and biological integrity of the Nation's waters"). 
8. 33 U.S.C. $\S 1251-1387$ (2006).

9. Id. § 1313; PUD No. 1 of Jefferson Cnty. v. Wash. Dep't of Ecology, 511 U.S. 700, 704 (1994) (citing 33 U.S.C. $\S \S 1311(b)(1)(C), 1313$ ).

10. 33 U.S.C. $\S \S 1313(d)-(e), 1329$.

11. See infra Part II.B.3.

12. See, e.g., Christopher Maag, From the Ashes of '69, a River Reborn, N.Y. TIMES, June 21, 2009, at A18.

13. See U.S. ENVTL. PROT. AGENCY, EPA 841-R-08001, NATIONAL WATER QUALITY INVENTORY: REPORT TO CONGRESS, 2004 REPORTING CYCLE 13-25 (2009).

14. This definition is consistent with that used in the extensive scientific literature on urban streams. See, e.g., Seth J. Wenger et al., Twenty-six Key Research Questions in Urban Stream Ecology: An Assessment of the State of the Science, 28 J. N. AM. BENTHOLOGICAL SOC'Y 1080, 1081 (2009) (defining urban "in the broadest possible sense").

15. See COMM. ON REDUCING STORMWATER DISCHARGE CONTRIBUTIONS TO WATER POLLUTION, NAT'L RESEARCH COUNCIL, URBAN STORMWATER MANAGEMENT IN THE UNITED STATES 20-26 (2009) [hereinafter NRC]; CTR. FOR WATERSHED PROT., IMPACTS OF IMPERVIOUS COVER ON AQUATIC SYSTEMS 2 (2003) [hereinafter CTR. FOR WATERSHED PROT.].

16. See CTR. FOR WATERSHED PROT., supra note 15 (explaining the impacts of development upon urban streams); Craig Anthony (Tony) Arnold, Clean Water Land Use: Connecting Scale and Function, 23 PACE ENVTL. L. REV. 291, 300-01 (2006) (same). 
17. See LUNA B. LEOPOLD, U.S. DEP'T OF THE INTERIOR, HYDROLOGY FOR URBAN LAND PLANNING—A GUIDEBOOK ON THE HYDROLOGIC EFFECTS OF URBAN LAND USE 15-17 (1968).

18. The literature of urban water quality protection often uses the terms or phrases "stormwater," "point source," and "nonpoint source," and different authors and reports use similar words in different ways. Compare, e.g., U.S. GEN. ACCOUNTABILITY OFFICE, GAO/RCED0054, KEY EPA AND STATE DECISIONS LIMITED BY INCONSISTENT AND INCOMPLETE DATA 5 (2000) (referring to pollution from urban development, which primarily means stormwater, as "nonpoint" source pollution), with NRC, supra note 15, at 14 (defining "stormwater" to include only stormwater discharged through point sources). I use "stormwater" to refer to water that precipitates during a storm event and then travels over the ground surface. I use the words "point source" and "nonpoint source" consistently with the CWA's definition of point source. See 33 U.S.C. § 1362(14) (2006). Under those definitions, most urban runoff qualifies as point source pollution because it passes through pipes or other "discrete conveyance[s]." Id. Thus, accounts that suggest that urban runoff is generally nonpoint source pollution are either using a nonlegal definition of point source or are simply mistaken.

19. See CTR. FOR WATERSHED PROT., supra note 15; NRC, supra note 15, at 13-35.

20. See NRC, supra note 15, at 339-459. Some of the most widely recommended measures include limiting impervious area, "disconnecting" impervious area so that runoff infiltrates into the subsurface rather than being piped directly to surface-receiving waters, preserving undeveloped buffers along urban waterways, and limiting (through a variety of technological and behavioral methods) pollutant loading onto urban landscapes. Id. 
21. See Wenger et al., supra note 14, at 1081 (identifying research questions).

22. See Wendy E. Wagner, Stormy Regulation: The Problems that Result when Stormwater (and Other) Regulatory Programs Neglect to Account for Limitations in Scientific and Technical Information, 9 CHAP. L. REV. 191, 191-93 (2006); NRC, supra note 15, at 47-122.

23. See OLIVER A. HOUCK, THE CLEAN WATER ACT TMDL PROGRAM: LAW, POLICY, AND IMPLEMENTATION 257-61 (2d ed. 2002).

24. See Interview with Don Witherill, Dir., Div. of Watershed Mgmt., Me. Dep't of Envtl. Prot., in Portland, Me. (June 11, 2009); Interview with Melissa Evers, Me. Dep't of Envtl. Prot., in Augusta, Me. (June 22, 2009); Telephone Interview with Christopher Bellucci, Conn. Dep't of Envtl. Prot. (July 8, 2009).

25. See infra Part II.B.

26. See infra Part III.

27. See infra Part III.B (describing residual designation authority).

28. See infra Part III.C (describing the proposed Long Creek permit).

29. See infra Part III.A.

30. The most detailed suggestions come from the National Research Council's 2008 study of urban stormwater pollution. See NRC, supra note 15, at 475-555. The innovations discussed and recommendations made in this article parallel some recommendations made by the NRC.

However, I focus to a larger extent on the role of mandates and incentives and explore in greater depth the legal practicalities of recommended reforms.

31. See infra notes $288-300$ and accompanying text. 
32. See infra notes 288-300 and accompanying text.

33. See, e.g., FB ENVTL. ASSOC., INC., supra note 5, at 80 ("The total cost to implement the Plan will be approximately $\$ 14$ million.”).

34. See, e.g., Emily S. Bernhardt \& Margaret A. Palmer, Restoring Streams in an Urbanizing World, 52 FRESHWATER BIOLOGY 738, 746-47 (2007).

35. Wenger et al., supra note 14, at 1092.

36. See, e.g., Allison H. Purcell et al., An Assessment of a Small Urban Stream Restoration Project in Northern California, 10 RESTORATION ECOLOGY 685, 689, 692-93 (2002);

Telephone Interview with Tom Blake, Mayor, City of S. Portland (Feb. 2, 2010) (describing potential benefits of restoration). Ecosystem services are non-monetized benefits that environmental systems provide to people. See James Salzman, Valuing Ecosystem Services, 24 ECOLOGY L.Q. 887, 887-88 (1997).

\section{See U.S. ENVTL. PROT. AGENCY, RESIDUAL DESIGNATION PURSUANT TO}

CLEAN WATER ACT: REGION I 3-6 (2008) (explaining mechanisms of degradation in Massachusetts' Charles River).

38. See Bernhardt \& Palmer, supra note 34, at 742; Richard J. Lazarus, Pursuing “Environmental Justice”: The Distributional Effects of Environmental Protection, 87 N.W. U. L. REV. 787, 788 (1993); Charles P. Lord et al., Natural Cities: Urban Ecology and the Restoration of Urban Ecosystems, 21 VA. ENVTL. L.J. 317, 320 (2003).

39. See, e.g., J.B. Ruhl \& James Salzman, Climate Change, Dead Zones, and Massive Problems in the Administrative State: A Guide for Whittling Away, 98 CAL. L. REV. 59, 61-67 (2010). 
40. See, e.g., Rapanos v. United States, 547 U.S. 715, 722 (2006) (decrying "the immense expansion of federal regulation of land use that has occurred under the Clean Water Act"); Cal. Bldg. Indus. Ass'n v. San Joaquin Valley Air Pollution Control Dist., 100 Cal. Rptr. 3d 204, 209-18 (Cal. Ct. App. 2009) (upholding a regional rule, promulgated in accordance with state obligations under the federal Clean Air Act, which regulated land development); Bruce Babbitt, The Endangered Species Act and "Takings": A Call for Innovation Within the Terms of the Act, 24 ENVTL. L. 355, 360 (1994) ("The ESA, with its focus on habitat, undeniably limits the freedom of some landowners ...."); Richard J. Lazarus, Super Wicked Problems and Climate Change: Restraining the Present to Liberate the Future, 94 CORNELL L. REV. 1153, 1164 (2009) (noting the need for land use controls to address climate change, but cautioning that "[1]and use controls are federal environmental law's 'third rail' ").

\section{See generally CASS R. SUNSTEIN, THE COSTBENEFIT STATE: THE FUTURE OF} REGULATORY PROTECTION (2002) (discussing the history of the cost-benefit state and outlining challenges created by the cost-benefit analysis); see also Frank Ackerman \& Lisa Heinzerling, Pricing the Priceless: Cost-Benefit Analysis of Environmental Protection, $150 \mathrm{U}$. PA. L. REV. 1553, 1583-84 (2002) (arguing that cost-benefit analysis is not an effective way of valuing environmental resources).

42. Another persistent environmental law theme is the importance and the difficulty of matching the informational demands of law to the capacity of science. See, e.g., Holly Doremus, Data Gaps in Natural Resource Management: Sniffing for Leaks along the Information Pipeline, 83 IND. L.J. 407 (2008); Wendy E. Wagner, Commons Ignorance: The Failure of Environmental Law to Produce Needed Information on Health and the Environment, 53 DUKE L.J. 1619 
(2004). As Parts II and III explain in detail, that challenge is centrally important to urban water quality management.

43. Margaret A. Palmer \& J. David Allan, Restoring Rivers, 22 ISSUES IN SCI. \& TECH. 40, 42 (2006) ("The primary reason why so many rivers and streams are still being degraded today is poor land stewardship.”).

44. This Article is a product of an ongoing research project also involving wa tershed ecologists and social scientists, and some of our subsequent research will focus on questions raised in this Article.

45. Many studies explore this relationship in more depth. For excellent syntheses, see CTR. FOR WATERSHED PROT., supra note 15, and NRC, supra note 15.

46. See Christopher J. Walsh et al., The Urban Stream Syndrome: Current Knowledge and the Search for a Cure, 24 J. N. AM. BENTHOLOGICAL SOC'Y 706, 707-08 (2005) (defining the symptoms associated with the urban stream syndrome).

47. See NRC, supra note 15 , at 131.

48. See id. at 156.

49. C.W. FETTER, APPLIED HYDROGEOLOGY 47-52 (Macmillan Coll. Publ'g Co. 3d ed. 1994).

50. Id.; see also NRC, supra note 15, at 153 ("Residence times generally increase from surface to subsurface flowpaths ....”).

51. See NRC, supra note 15 , at $158-62$. 
52. See Robert T. LeBlanc et al., Modeling the Effects of Land Use Change on the Water

Temperature in Unregulated Urban Streams, 49 J. ENVTL. MGMT. 445, 465 (1997).

53. CTR. FOR WATERSHED PROT., supra note 15, at 39, 49 (explaining the importance of large woody debris).

54. For a description of filtering mechanisms, see Michael G. Dosskey, Toward Quantifying

Water Pollution Abatement in Response to Installing Buffers on Crop Land, 28 ENVTL. MGMT.

$577,584-85(2001)$.

55. See Stanley v. Gregory et al., An Ecosystem Perspective of Riparian Zones, 41

BIOSCIENCE 540, 545-49 (1991).

56. When urbanization displaces agricultural use, the picture is more complex. Urbanization then may accelerate changes in the natural flow regime and increase aggregate pollutant loading, but some individual pollutant loads may decrease. See NRC, supra note 15, at 177; Wenger et al., supra note 14 , at 1084.

57. Turf, though usually considered a pervious surface, often grows over compacted soils with less infiltration capacity than undeveloped areas. Turf therefore falls into an intermediate category. See NRC, supra note 15, at 139-40.

58. Bernhardt \& Palmer, supra note 34 , at 740.

59. NRC, supra note 15 , at 166-70.

60. Bernhardt \& Palmer, supra note 34 , at 740.

61. See, e.g., ROBERT GLENNON, WATER FOLLIES: GROUNDWATER PUMPING AND THE FATE OF AMERICA'S FRESH WATERS 99-111 (2002) (discussing urbanization in 
Massachusetts' Ipswich River watershed). For extensive discussion of urbanization and water supply, see WET GROWTH: SHOULD WATER LAW CONTROL LAND USE? (Craig Anthony Arnold ed. 2005) [hereinafter WET GROWTH].

62. See Bernhardt \& Palmer, supra note 34 , at 740 . Changing precipitation patterns associated with climate change are likely to exacerbate this flashiness. See Arthur T. DeGaetano, TimeDependent Changes in Extreme Precipitation Return Period Amounts in the Continental United States, 48 J. APPLIED METEOROLOGY \& CLIMATOLOGY 2086, 2087 (2009) (summarizing studies predicting increased frequency of extreme precipitation events). An exception to this trend toward increased flashiness can exist where wastewater effluent or recharge from excess landscape irrigation produce artificially steady flows. See NRC, supra note 15 , at $155,193$.

63. See NRC, supra note 15 , at 176-92.

64. See CENTER FOR WATERSHED PROTECTION, supra note 15, at 55-92.

65. See id. at 91 . The primary exception is fertilizer and pesticide loading, which derives primarily from lawns and landscaped areas. See id. at 69.

66. See NRC, supra note 15, at 204.

67. The CWA defines heat as a pollutant. See 33 U.S.C. § 1362(6) (2006).

68. CTR. FOR WATERSHED PROT., supra note 15, at 50; Wenger et al., supra note 14, at 1087. 
69. CTR. FOR WATERSHED PROT., supra note 15, at 58; NRC, supra note 15, at 268 (describing "firstflush effects"). For discussion of snowmelt, see NRC, supra note 15, at 196203.

70. "Combined sewer systems are sewers that are designed to collect rainwater runoff, domestic sewage, and industrial wastewater in the same pipe." Combined Sewer Overflows, U.S. ENVTL. PROT. AGENCY, http://cfpub.epa.gov/npdes/home.cfm?program_id=5 (last visited Oct. 28, 2010).

71. See Charles Duhigg, As Sewers Fill, Waste Poisons Waterways, N.Y. TIMES, Nov. 22, 2009, at A1.

72. See NRC, supra note 15, at 162-66.

73. CTR. FOR WATERSHED PROT, supra note 15, at 49.

74. Id. at 32-48. That erosion also increases the sediment load of the stream. See NRC, supra note 15 , at 174 ("[T] urbanizing watershed ....”).

75. See CTR. FOR WATERSHED PROT., supra note 15, at 39. The term substrate refers to the sedimentary material — silt, sand, gravel, or boulders, for example — that compose the bed of the stream.

76. See id. at 3 ("A negative relationship between watershed development and nearly all of the 26 stream quality indicators has been established over many regions and scientific disciplines."). 
77. See, e.g., Seth J. Wenger et al., Stream Fish Occurrence in Response to Impervious Cover, Historic Land Use, and Hydrogeomorphic Factors, 65 CAN. J. FISH \& AQUATIC SCI. 1250, 1251 (2008) (describing impacts to species protected by the Endangered Species Act).

78. See NRC, supra note 15, at 220, 231; Wenger et al., supra note 14, at 1083. The mix of species also tends to shift, with more tolerant species becoming more predominant. See A. H. Roy et al., Investigating Hydrologic Alteration as a Mechanism of Fish Assemblage Shifts in Urbanizing Streams, 24 J. N. AM. BENTHOLOGICAL SOC'Y 656, 672 (2005).

79. See CTR. FOR WATERSHED PROT., supra note 15, at 40. Those floods can be destructive and dangerous. See Arnold, supra note 16, at 300-01.

80. CTR. FOR WATERSHED PROT., supra note 15, at 1-2; NRC, supra note 15, at 226-30. The 10 percent and 25 percent thresholds "are not sharp 'breakpoints," " and the percentage of impervious cover in a watershed "[d]oes not predict the precise score of an individual stream water quality indicator ...." CTR. FOR WATERSHED PROT., supra note 15, at 2-3.

81. See CTR. FOR WATERSHED PROT., supra note 15, at 9 (“[M] ost suburban and even rural zoning categories exceed $10 \%$ IC ....”).

82. See Thomas F. Cuffney et al., Responses of Benthic Macroinvertebrates to Environmental Changes Associated with Urbanization in Nine Metropolitan Areas, 20 ECOLOGICAL APPLICATIONS 1384, 1398 (2010); Wenger et al., supra note 77, at 1250.

83. See NRC, supra note 15 , at 220.

84. See id. at 229. 
85. See U.S. ENVTL. PROT. AGENCY, supra note 13, at 16, 19, 23; U.S. ENVTL. PROT. AGENCY, supra note 37, at 3-6 (documenting degradation of the Charles River watershed).

86. The Center for Watershed Protection's website links many articles discussing restoration techniques. CTR. FOR WATERSHED PROT., http://www.cwp.org/ (last visited Oct. 25, 2010). 87. "A green roof . . . is a vegetative layer grown on a rooftop." Green Roofs, U.S. ENVTL. PROT. AGENCY, http://www.epa.gov/heatisland/mitigation/ greenroofs.htm (last visited Feb. 23, 2010).

88. See id.; NRC, supra note 15, at 142.

89. See, e.g., NRC, supra note 15, at 137 (showing connected and disconnected roof drains).

90. For example, "[1] ead concentrations in stormwater have ... significantly decreased since the elimination of lead in gasoline ...." Id. at 260.

91. See, e.g., Me. Dept. of Envtl. Prot., Think Blue Rubber Ducky Ad, MAINE.GOV (June 15, 2009) http://media.maine.gov/cgibin/vid?id =utCwkeLRt3cLdLY.

92. See, e.g., CTR. FOR WATERSHED PROT., supra note 15, at 21-22 (“[N]o community has yet demonstrated that they can achieve water quality standards in an urban watershed that exceeds 25\% IC."); see generally Wenger et al., supra note 14, at 1091-92 (identifying the need for realistic consideration of restoration goals).

93. See 33 U.S.C. $§ 1342$ (2006).

94. Id. $\S 1362(12)$ (defining “discharge of a pollutant”); id. $\S 1311($ a) (establishing a general prohibition on unpermitted discharges of pollutants). For a discussion of exceptions to this general rule, see infra Part III.B. 
95. See 33 U.S.C. § 1362(14); supra note 14.

96. See 33 U.S.C. § 1311(a). 446 UNIVERSITY OF COLORADO LAW REVIEW [Vol. 82

97. See id. §§1316-17.

98. Id. $§ 1318$.

99. Id. $\S 1319,1365$.

100. See, e.g., Bruce A. Ackerman \& Richard B. Stewart, Reforming Environmental Law, 37

STAN. L. REV. 1333, 1333-40 (1985); Cass R. Sunstein, Administrative Substance, 1991

DUKE L.J. 607, 627-30.

101. See, e.g., Wagner, supra note 22, at 198-201.

102. For a summary of the debate over these standards, see Jonathan Cannon, A Bargain for Clean Water, 17 N.Y.U ENVTL. L.J. 608, 618-21 (2008).

103. See, e.g., Wagner, supra note 22.

104. See NRC, supra note 15, at 329 (describing monitoring and modeling as "what might be the two weakest areas of the stormwater program"); Jeffrey M. Gaba, Generally Illegal: NPDES General Permits Under the Clean Water Act, 31 HARV. ENVTL. L. REV. 409, 429 (2007) ("The regulation of point source discharges of contaminated storm water has, since the earliest days of the NPDES permit program, posed problems for EPA.”).

105. See Wagner, supra note 22, at 201 (asserting, with caveats, that "the NPDES program exemplifies smart regulatory design"). 
106. See NRC, supra note 15, at 266 (describing sampling methodologies), 276- 77 (describing problems experienced by communities responsible for monitoring).

107. See id. at 258.

108. See id. at 262, 266, 284. The University of Alabama has compiled a national stormwater database, however, which can help municipal stormwater managers predict site-specific conditions without extensive outfall monitoring. See ROBERT PITT ET AL., NATIONAL STORMWATER QUALITY DATABASE (2004), available at http://unix.eng.ua.edu/ rpitt/Research/ms4/Paper/MS4 Feb 162004 pa per.pdf.

109. See supra notes 59-85 and accompanying text.

110. See Wagner, supra note 22, at 203 (explaining the different approaches).

111. See 33 U.S.C. $\S \S 1316-17$ (2006).

112. See Wagner, supra note 22, at 206, 209.

113. See NRC, supra note 15, at 258; Wagner, supra note 22, at 210.

114. See Wagner, supra note 22, at 205, 213, 217. One cannot assume that implemented BMPs are fully effective, for there are substantial "error bars and uncertainties surrounding the pollution control capabilities of various BMPs . ...” Id. at 203.

115. See id. at $220-21$.

116. See id. at 216-17.

117. The EPA's “menu” of municipal stormwater BMPs does include BMPs designed to address flow levels and impervious area. See Post-Construction Storm water Management in New 
Development and Redevelopment, U.S. ENVTL. PROT. AGENCY, http://cfpub1.epa.gov/npdes/stormwater/menuofbmps/index.cfm?action= min_meaure\&min_measure_id=5 (last visited Nov. 17, 2010). But these are optional measures that a community can implement, or not, largely at its discretion. Industrial permittees also have wide discretion to select BMPs. See Wagner, supra note 22, at 216-17. But the parameters they are supposed to monitor and control, and that BMPs therefore would be likely to address, generally do not include temperature or runoff volume. See NRC, supra note 15, at 73-74 (listing parameters).

118. See 33 U.S.C. $\S 1311$ (a) (2006) (prohibiting discharges of pollution); id. $§ 1362(12)$ (defining discharges as additions of pollution to navigable waters from point sources); id. $\S$ 1362(14) (defining point sources).

119. See Natural Res. Def. Council, Inc. v. Costle, 568 F.2d 1369 (D.C. Cir. 1977).

120. See 33 U.S.C. $§ 1342(p)$. The legislative history for these amendments indicates that members of Congress viewed the amendments as an appropriate compromise that would focus regulation only on those point sources of stormwater that actually were harming water qualityand that those members believed, incorrectly, that most developed areas were causing no such harm. See, e.g., 133 CONG. REC. 985 (1987) (statement of Rep. Hammerschmidt) ("We established a mechanism that will require permits only where necessary - rather than in every instance. Without these changes, local, State, and Federal officials would be in undated with an enormous permitting workload even though most of the discharges would not have significant environmental impacts."). It also suggests that at least some members believed, incorrectly, that many stormwater sources, including drainage from impervious surfaces, were environmentally innocuous. E.g., 131 CONG. REC. 20,006 (1985) (statement of Rep. Rowland) (“Without any 
compromise to the environment or reduction in the commitment to clean water we can prevent unnecessary diversion of personnel and other resources to an unproductive paper shuffling exercise by not requiring permits for rainwater runoff from parking lots . ...”).

121. See 33 U.S.C. $\S 1342(p)(2)$. For a detailed recounting of the subsequent regulatory negotiations, which eventually did lead to regulation of the required categories, see Erin Ryan, Federalism and the Tug of War Within: Seeking Checks and Balance in the Interjurisdictional Gray Area, 66 MD. L. REV. 503, 567-80 (2007).

122. 40 C.F.R. $\S 122.26(a)$ (2010). Many regulated sources still fail to obtain permits. See Wagner, supra note 22, at 211-12.

123. See 33 U.S.C. § 1342(p); Conservation Law Found. v. Hannaford Bros., 327 F.Supp.2d 325, 330-35 (D. Vt. 2004) (rejecting an argument that CWA section 301(a) requires permits for all point sources of stormwater, even in the absence of a residual designation). Some landowners are regulated indirectly, with the municipal stormwater manager compelled to meet its obligations by regulating private owners. But local water managers still may feel that controlling private stormwater management practices strains their regulatory authority and political clout. See Interview with Patrick Cloutier, supra note 3. Also, requirements for municipal permittees generally do not focus on the impacts of existing impervious cover, and requirements for new development are only very generally stated. See 40 C.F.R. $\S 122.34$.

124. See infra Part III.B.

125. E.g., CITY OF PORTLAND, STORMWATER MANAGEMENT MANUAL 1-3 (2008) (describing NPDES permitting obligations as a primary impetus for the creation of Portland, Oregon's comprehensive and detailed stormwater management manual); Interview with Patrick 
Cloutier, supra note 3; Interview with Brenda Zollitsch, Facilitator, Bangor Area Stormwater Network, in Portland, Me. (January 4, 2010). Both Mr. Cloutier and Ms. Zollitsch described extensive efforts pursuant to the EPA's municipal separate storm sewer system (MS4) program.

126. See, e.g., ENVTL. PROT. AGENCY, WATERSHEDBASED PERMITTING CASE STUDY: MICHIGAN STATEWIDE STORMWATER PERMITTING (2007), available at http://www.epa.gov/npdes/pubs/wq_casestudy_factsht3.pdf(describing a successful effort in Michigan's Rouge River watershed); ENVTL. PROT. AGENCY, WATERSHED-BASED PERMITTING CASE STUDY: TUALATIN RIVER WATERSHED, OREGON 1 (2007), available at $\mathrm{http}: / / \mathrm{www} . \mathrm{epa} . g o v / \mathrm{npdes} / \mathrm{pubs} / \mathrm{wq}$ casestudy_factsht4.pdf.

127. E.g., ENVTL. PROT. AGENCY, GENERAL PERMITS FOR STORMWATER DISCHARGES FROM SMALL MUNICIPAL SEPARATE STORM SEWER SYSTEMS: AUTHORIZATION TO DISCHARGE UNDER THE NATIONAL POLLUTANT DISCHARGE ELIMINATION SYSTEM (2008), available at http://www.epa.gov/NE/npdes/ stormwater/nh/DraftNHSmallMS4Permit.pdf (draft of general permit for parts of New England, which includes requirements for inventorying and mapping impervious surfaces).

128. E.g., NRC, supra note 15, ch. 6 .

129. 33 U.S.C. $\S 1313(d)(1)(C)(2006)$.

130. Id. § 1312(b)(2).

131. Id. § 1313(e); see also 40 C.F.R. § 130.6 (2010).

132. See Pronsolino v. Nastri, 291 F.3d 1123, 1126 (9th Cir. 2002). 
133. HOUCK, supra note 23, at 12-24, 49-56; see also, e.g., Sierra Club v. Hankinson, 939 F. Supp. 865, 871-72 (N.D. Ga. 1996) (describing Georgia's poor progress).

134. HOUCK, supra note 23, at 49-56.

135. See LEONARD SHABMAN ET AL., ADAPTIVE IMPLEMENTATION OF WATER QUALITY IMPROVEMENT PLANS: OPPORTUNITIES AND CHALLENGES 28 (2007)

("More than 40,000 TMDLs remain to be implemented ....").

136. 33 U.S.C. $\S 1313(d)(2006)$.

137. 40 C.F.R. $\S 130.7(a)(2010)$.

138. Id. $\S 130.7(\mathrm{c})(1)$.

139. Because most point source stormwater discharges are subject to general permits, and because translating TMDL requirements into specific source controls requires information that isn't readily available, tailoring permit requirements to the needs of specific watersheds may be difficult, if not impossible. See Gaba, supra note 104, at 434-35, 439-40.

140. 33 U.S.C. $\S 1312$.

141. Id. $\S 1313(\mathrm{e})$.

142. Id. $\S 1329(\mathrm{~h})$.

143. Pronsolino v. Nastri, 291 F.3d 1123, 1140 (9th Cir. 2002) (“States must implement TMDLs only to the extent that they seek to avoid losing federal grant money . ...").

144. William F. Pedersen, Jr., Turning the Tide on Water Quality, 15 ECOLOGY L.Q. 69, 80 (1988). 
145. See HOUCK, supra note 23, at 204-05.

146. See, e.g., BRIAN BENHAM ET AL., TMDL IMPLEMENTATION -

CHARACTERISTICS OF SUCCESSFUL PROJECTS 10-11 (2006); ENVTL. PROT.

AGENCY, WATERSHEDBASED PERMITTING CASE STUDY: LONG ISLAND SOUND, CONNECTICUT 2 (2007), available at http://www.epa.gov/npdes/pubs/wq_casestudy

_factsht1.pdf (describing a TMDL spurring state regulatory efforts); ENVTL. PROT. AGENCY, WATERSHED-BASED PERMITTING CASE STUDY: NEUSE RIVER WATERSHED, NORTH CAROLINA 6 (2007), available at http://www.epa.gov/npdes/

pubs/wq_casestudy_factsht11.pdf (quoting a North Carolina Department of Environmental Quality representative, who observed that, for a watershed permitting organization to function effectively, "[t]here needs to be a TMDL to drive the need for membership").

147. 33 U.S.C. $\S 1313(d)(1)(C)-(D)(2006)$.

148. Interview with Don Witherill, supra note 24; Interview with Melissa Evers, supra note 24; Interview with Christopher Bellucci, supra note 24. Informational challenges are by no means unique to urban stormwater TMDLs. See U.S. GEN. ACCOUNTABILITY OFFICE, supra note 18; SHABMAN ET AL., supra note 135, at 14-20; Daniel C. Esty, Toward Optimal Environmental Governance, 74 N.Y.U. L. REV. 1495, 1528 (1999) (“A central reason for the slow progress [in addressing water pollution] can be traced to a lack of information.”).

149. See supra Part II.A.

150. See 33 U.S.C. $§ 1362(6)$ (2006) (defining “pollutant”); id. § 1362(19) (defining “pollution" as "the manmade or maninduced alteration of the chemical, physical, biological, and radiological 
integrity of water"); Reed D. Benson, Pollution Without Solution: Flow Impairment Problems

Under Clean Water Act Section 303, 24 STAN. ENVTL. L. J. 199, 235-36 (2005).

151. See supra Part II.A.

152. Interview with Don Witherill, supra note 24; Interview with Melissa Evers, supra note 24; Interview with Christopher Bellucci, supra note 24.

153. Interview with Melissa Evers, supra note 24; Interview with Christopher Bellucci, supra note 24 .

154. Interview with Don Witherill, supra note 24. Witherill explained that the Long Creek restoration project proceeded without a TMDL largely because earlier studies of the watershed provided more information than a TMDL report would contain. Id.

155. Id.

156. PUD No. 1 of Jefferson Cnty. v. Wash. Dep’t of Ecology, 511 U.S. 700, 723 (1994)

(Stevens, J., concurring) ("Not a single sentence, phrase, or word in the CWA purports to place any constraint on a State's power to regulate the quality of its own waters more stringently than federal law might require.").

157. See, e.g., ME. REV. STAT. tit. 38, § 420D (2010) (requiring stormwater permits for any "project that includes one acre or more of disturbed area"); MD. CODE REGS. 26.17 .02 (2009). 158. E.g., Chang-Hee Christine Bae, Salmon Protection in the Pacific Northwest: Can it Succeed?, 17 N.Y.U. ENVTL. L.J. 559, 561-66 (2008) (describing local controls imposed pursuant to Washington's Growth Management Act). 
159. E.g., MD. CODE ANN., NAT. RES. $§ 81808.3$ (2010) (establishing coverage limits for developments near Chesapeake Bay); In re Protest of Coastal Permit Program Rules, 807 A.2d 198, 207, 232-37 (N.J. Super. Ct. App. Div. 2002) (upholding limitations on impervious area); ENVTL. PROT. AGENCY, WATERSHEDBASED PERMITTING CASE STUDY: BIG DARBY CREEK, OHIO (2007), available at http://www.epa.gov/npdes/pubs/wq_casestudy_factsht12.pdf(describing control measures including development limits for areas near streams); see, e.g., Riparian Forest Buffer Restoration: Maryland Stream ReLeaf, MD. DEP'T OF NATURAL RES., http://www.dnr.maryland.gov/forests/programapps/rfbrestoration.asp (last visited Nov. 1, 2010) (describing an incentive-based program).

160. See, e.g., OR. DEP'T OF LAND CONSERVATION \& DEV. \& OR. DEP'T OF ENVTL. QUALITY, WATER QUALITY MODEL CODE AND GUIDEBOOK (2000), available at http://www.oregon.gov/LCD/waterqualitygb.shtml.

161. For example, Portland (Oregon), Austin, Seattle, the Lake Tahoe basin in California, and Nevada are commonly identified as leaders in local regulation. See Sustainable Stormwater Management Solutions, PORTLAND BUREAU OF ENVTL. SERVS., http://www.portlandonline.com/bes/index.cfm?c=31870 (last visited Nov. 1, 2010); Watershed Ordinances: A Retrospective, CITY OF AUSTIN, https://www.ci.austin.tx.us/watershed/ordinances.htm (last visited Nov. 1, 2010); Stormwater Management Program, SEATTLE PUB. UTILS., http:/www.seattle.gov/ util/About_SPU/Drainage_\&_Sewer_System/Plans/StormwaterManagementProgram/index.htm (last visited Nov. 1, 2010); Derek Kauneckis \& Mark T. Imperial, Collaborative Watershed Governance in Lake Tahoe: An Institutional Analysis, 10 INT'L J. OF ORG. THEORY AND 
BEHAV. 503 (2007) (describing the evolution of the Lake Tahoe basin's regulatory approach). Duluth, Minnesota provides an interesting case study of an advanced informational approach. See LAKE SUPERIOR DULUTH STREAMS, http://www.lakesuperiorstreams.org/ (last visited Nov. 1, 2010).

162. In Maine, for example, state-law limits on runoff from new developments provide a valuable preventive complement to residual designation authority, TMDLs, and other regulatory provisions with more of a remedial focus. See ME. REV. STAT. tit. 38, § 420D (2010); 06096500 ME. CODE R. $\S 4$ (LexisNexis 2006). In conversations, however, state regulators consistently told me they view those requirements, while helpful, as insufficient to mitigate all impacts of development.

163. I base this assertion on a research assistant's survey of state regulatory requirements (on file with the author), which revealed that only a small minority of states have requirements that exceed the federal program in scope or stringency.

164. See id.

165. See Charles Duhigg, Clean Water Laws Neglected, at a Cost, N.Y. TIMES, Sept. 13, 2009, at A1.

166. See William L. Andreen, Federal Climate Change Legislation and Preemption, 3 ENVTL. \& ENERGY L. \& POL'Y J. 261, 279-80 (2008); Andrew Hecht, Obstacles to the Devolution of Environmental Protection: States' Self-Imposed Limitations on Rulemaking, 15 DUKE ENVTL. L. \& POL'Y F. 105 (2004).

167. See generally, HOUCK, supra note 23 (describing states' reluctance to develop and implement TMDLs). 
168. See Duhigg, supra note 165 , at A1.

169. 16 U.S.C. $\S \S 1531-44$ (2006).

170. See supra Part II.A.

171. See, e.g., Wenger et al., supra note 77, at 1257 (documenting species' disappearance at low effective impervious cover levels). These quick disappearances do raise the possibility, however, that the ESA could provide protection in some areas at early stages of urbanization.

172. See Nat'l Ass'n of Home Builders v. Defenders of Wildlife, 551 U.S. 644 (2007) (holding that the EPA's delegations of NPDES permitting authority to states are not subject to consultation under section 7 of the ESA); Rapanos v. United States, 547 U.S. 715 (2006) (limiting federal wetlands authority); Solid Waste Agency of N. Cook Cnty. v. Army Corps of Eng'rs, 531 U.S. 159 (2001) (same).

173. 16 U.S.C. $\S 1536(a)$.

174. See Daniel J. Rohlf, Jeopardy Under the Endangered Species Act: Playing a Game Protected Species Can't Win, 41 WASHBURN L.J. 114, 141-42 (2001); J.B. Ruhl, Keeping the Endangered Species Act Relevant, 19 DUKE ENVTL. L. \& POL'Y F. 275, $284-85$ (2009).

175. 16 U.S.C. § 1538; see also Eric Biber, The Application of the Endangered Species Act to the Protection of Freshwater Mussels: A Case Study, 32 ENVTL. L. 91, 152-53 (2002) (discussing some of the challenges of showing causation where multiple actors are responsible for water quality degradation that impacts species).

176. Babbitt v. Sweet Home Chapter of Cmtys. for a Great Or., 515 U.S. 687, 700 n.13 (1995); see also id. at 708-09 (O’Connor, J., concurring). 
177. In researching another article, I recently obtained all fish-related biological opinions generated by the Fish and Wildlife Service and the National Marine Fisheries Service. While many of the opinions address species affected by urbanization, the agencies rarely formally consult on development projects unless the project is either directly adjacent to or crosses a stream inhabited by listing species.

178. See Defenders of Conewango Creek v. Echo Developers, L.L.C., 2007 WL 3023927 (W.D. Pa. 2007) (rejecting a challenge to a shopping complex); Ctr. for Biological Diversity v. U.S. Fish \& Wildlife Serv., 202 F. Supp.2d 594, 597 (W.D. Tex. 2002) (rejecting ESA claims against the Fish and Wildlife Service and a developer that wished "to profit from suburban consumerism by transforming Nature's beauty into upscale shopping venues accompanied no doubt by lovely, nonporous asphalt parking lots over a part of our water supply").

179. Etowah Aquatic HCP Overview, ETOWAH AQUATIC HABITAT CONSERVATION PLAN, http://www.etowahhcp.org/background/overview.htm (last visited Nov. 1, 2010) [hereinafter ETOWAH HABITAT CONSERVATION PLAN]; see also Seth J. Wenger et al., Runoff Limits: An Ecologically Based Stormwater Management Program, 9 STORMWATER 1 (2008) (describing the Etowah initiative).

180. See Kathie Durbin, The Costs of Growth; Environment - Saving Salmon Might Change Subdivisions, Hurt Efforts to Limit Sprawl, COLUMBIAN, Nov. 2, 2001, at C1.

181. Edwards Aquifer Authority, Edwards Aquifer Authority Contemplates New Regulations to Strengthen Water Quality Protection, AQUIFER GUARDIANS IN URBAN AREAS (Aug. 11, 2009), http://www.aquiferguardians.org/eaaimpervlimit.htm. 
182. Two of the many cases that precipitated these efforts were Sierra Club v. Glickman, 156 F.3d 606 (5th Cir. 1998) (upholding an injunction requiring protection of listed species) and Save Our Springs v. Babbitt, 27 F. Supp.2d 739 (W.D. Tex. 1997) (requiring action on a petition to list a species as threatened or endangered).

183. See, e.g., ENVTL. PROT. AGENCY, supra note 127, at 7, App. C.

184. The adverse modification prohibition has been relatively unimportant because no critical habitat has been designated for most listed species, see Species Reports, U.S. FISH AND WILDLIFE SERVICE, http://ecos.fws.gov/tess_public/pub/listedAnimals.jsp (last updated Nov. 10, 2010), and because the implementing agencies' regulations make the adverse modification inquiry essentially superfluous. See 50 C.F.R. § 402.02 (2010) (defining “[d]estruction or adverse modification" and "[j]eopardize the continued existence of"); Rohlf, supra note 174, at 118-19 (criticizing the regulatory approach). Courts have "almost unanimously" held that critical habitat designations are mandatory, however, and have rejected the agencies' regulatory approach. Jason M. Patlis, Paying Tribute to Joseph Heller with the Endangered Species Act: When Critical Habitat Isn't, 20 STAN. ENVTL. L.J. 133, 177 (2001); see also, e.g., Gifford Pinchot Task Force v. U.S. Fish \& Wild life Serv., 378 F.3d 1059, 1069-71 (9th Cir. 2004). 185. See supra Part II.A.

186. See, e.g., J.B. Ruhl, Regulation by Adaptive Management—Is it Possible?, 7 MINN. J.L. SCI. \& TECH. 21, 21-22 (2005) (describing these kinds of challenges as the "low-hanging fruit”); Esty, supra note 148, at 1545-46 (“[T]he harder a problem is to see and the broader the spread of the harm across space or time, the more likely it is that externalities will not be internalized and that an appropriate degree of collective action will not be achieved."). 
187. See generally Ruhl \& Salzman, supra note 39 (exploring the challenges created by cumulative and complex environmental problems).

188. Interview with Brenda Zollitsch, supra note 125 (explaining that people generally do not understand how stormwater moves, that small individual contributions collectively create significant pollution problems, or even what a watershed is).

189. See, e.g., Cal. Bldg. Indus. Ass'n v. San Joaquin Valley Air Pollution Control Dist., 100 Cal. Rptr. 3d 204 (Cal. Ct. App. 2009) (upholding an air pollution district's indirect source rule); Henry Stern, A Necessary Collision: Climate Change, Land Use, and the Limits of A.B. 32, 35 ECOLOGY L.Q. 611, 611 (2008).

190. See HOUCK, supra note 23, at 64 (describing citizen suits as "the reason American [environmental] laws work where the similar and often stronger-looking laws of other countries do not"); Barton H. Thompson, Jr., The Continuing Innovation of Citizen Enforcement, $2000 \mathrm{U}$. ILL. L. REV. 185, 185.

191. See supra Part II.B.2.

192. See, e.g., CONN. DEP'T OF ENVTL. PROT., A TOTAL MAXIMUM DAILY LOAD ANALYSIS FOR EAGLEVILLE BROOK, MANSFIELD, CONN. (2007); ME. DEP'T OF ENVTL. PROT. \& SUSANNE MEIDEL, TROUT BROOK TOTAL MAXIMUM DAILY LOAD (2007) [hereinafter TROUT BROOK TMDL].

193. See also VT. DEP'T OF ENVTL. CONS., TOTAL MAXIMUM DAILY LOAD TO ADDRESS BIOLOGICAL IMPAIRMENT IN POTASH BROOK, CHITTENDON COUNTY 4 (2006) (using total stormwater runoff volume as the proxy); NRC, supra note 15, at 491-92 (advocating impervious cover TMDLs). 
194. See, e.g., TROUT BROOK TMDL, supra note 192, at 17-18.

195. See id. All impervious cover TMDLs focus on treating existing impervious area; no one suggests that buildings, parking lots, and roads should simply be removed.

196. Interview with Melissa Evers, supra note 24; Interview with Don Witherill, supra note 24.

197. See Jeff Dennis \& Allison Piper, Summary of the Method Used to Develop an Algorithm to Predict the \% Imperviousness of Watersheds, ME. DEP'T OF ENVTL. PROT., http://www.maine.gov/dep/blwq/docstand/stormwater/method.pdf (last visited Dec. 16, 2009).

198. See 33 U.S.C. $§ 1362(6)$ (2006).

199. See supra Part II.A.

200. See Chester L. Arnold et al., Responding to the First Impervious Coverbased TMDL in the Nation, 1 WATERSHED SCI. BULL. 11, 17 (2010).

201. See Interview with Patrick Cloutier, supra note 3 (stating that impervious cover TMDLs are helpful for local officials); WET GROWTH, supra note 60, at 35 ("The land use planner or regulator ... thinks spatially.”).

202. A full set of recommendations for reforming the CWA's TMDL provisions is beyond the scope of this Article. But legislative reforms are needed, and the problems discussed here suggest the value of giving states more flexibility in selecting TMDL approaches and less flexibility to decide whether or not to turn TMDLs into actual pollution controls.

203. 33 U.S.C. $\S 1313(d)$.

204. See Friends of the Earth v. EPA, 446 F.3d 140, 148 (D.C. Cir. 2006) (rejecting TMDLs that established seasonal or annual loads); Minn. Ctr. for Envtl. Advocacy v. EPA, 2005 WL 
1490331, at *5 (D. Minn. June 23, 2005) (rejecting a “basinwide TMDL” approach); but see Natural Res. Def. Council v. Muszynski, 268 F.3d 91, 99 (2d Cir. 2001) (allowing nondaily loads). See generally David S. Tatel, The Administrative Process and the Rule of Environmental Law, 34 HARV. ENVTL. L. REV. 1, 3-4 (2010) (discussing the Friends of the Earth decision). A challenge to a similar approach may be brewing in Virginia. See Aaron Lovell, Novel Region III TMDL May Test EPA's Ability to Regulate Water Flow, INSIDE EPA, Sept. 10, 2010.

205. See Robert L. Glicksman, Bridging Data Gaps Through Modeling and Evaluation of Surrogates: Use of the Best Available Science to Protect Biological Diversity Under the National Forest Management Act, 83 IND. L.J. 465, 483-84 (2008).

206. See supra notes $63-71$ and accompanying text.

207. This problem is not unique to impervious cover TMDLs; some traditional TMDLs suffer the same flaw.

208. CENTER FOR WATERSHED PROTECTION, supra note 15, at 3, 9-12 (describing this issue as "[t]he most hotly debated question about the ICM"); Wenger et al., supra note 14, at 1085 (identifying several questions related to the effectiveness of treatments).

209. E.g. TROUT BROOK TMDL, supra note 192 (omitting this information); see also Interview with Don Witherill, supra note 24 (noting this limitation of impervious cover TMDLs).

210. See 33 U.S.C. $\S 1342(p)(2)$ (2006). Another possible fix to the problems identified here would be a CWA amendment narrowing those default criteria.

211. See supra notes 104-23 and accompanying text. 
212. 33 U.S.C. $§ 1342(p)(2)(E)(2006)$.

213. 40 C.F.R. $\S 122.26(f)(2)(2010)$.

214. Section 402(p) is structurally similar to section 202 of the Clean Air Act, which requires a determination based on statutory criteria once a petition is filed. See Massachusetts v. EPA, 549 U.S. 497, 528 (2007) (describing section 202 of the Clean Air Act).

215. 33 U.S.C. § 1342(p)(2)(E) (emphasis added). Section 1342(p)(2) exempts some stormwater sources from permitting requirements, but states that this exemption "shall not apply" to stormwater discharges described in the subsections of 1342(p)(2), including those listed pursuant to subsection (p)(2)(E). Consequently, the normal prohibition on nonpermitted point source discharges applies.

216. No law review articles discuss the subject, the EPA's recent publications rarely refer to it, and I have found only one published decision addressing the use of residual designation authority. See In re Stormwater NPDES Petition, 910 A.2d 824 (Vt. 2006). However, both Congress and the EPA seem to have expected extensive use of this provision. The legislative history of the 1987 CWA amendments suggests that Congress perceived this provision as an important mechanism. See, e.g., 132 CONG REC. 32,381 (Oct. 16, 1986) (Statement of Sen. Stafford) ("EPA and the States must require permits when either determines that a storm sewer contributes to a violation of water quality standards or is a significant contributor of pollutants to waters of the United States.”). And in 1990, an EPA guidance memo suggested that residual designation authority should see immediate and widespread use. Memorandum from James R. Elder, Office of Water Enforcement and Permits, to Water Management Division Directors, Regions IX, and NPDES State Directors (August 8, 1990) (on file with author). 
217. See supra Part II.A.

218. See U.S. ENVTL. PROT. AGENCY, supra note 37.

219. VT. AGENCY OF NATURAL RES. AND DEP’T OF ENVTL. CONSERVATION, FINAL DESIGNATION PURSUANT TO THE CLEAN WATER ACT FOR DESIGNATED DISCHARGES TO BARTLETT, CENTENNIAL, ENGLESBY, MOREHOUSE AND POTASH BROOKS (2009), available at http://www.vtwaterquality.org/stormwater/docs/ swimpairedwatersheds/sw_rda_final_determination.pdf.

220. See Interview with Steve Hinchman, Staff Attorney, Conservation Law Found., in Portland, Me. (May 29, 2009) (describing Long Creek as a "poster child for every coastal stream in (southern) Maine").

221. See Elder Memorandum, supra note 216 (suggesting, as examples, that residual designation authority could be used for water bodies in Washington, Minnesota, Illinois, Michigan, Texas, and the Chesapeake Bay watershed).

222. See Telephone Interview with Chris Kilian, Vt. Dir., Conservation Law Found. (Mar. 4, 2010) (stating that other environmental groups are increasingly learning about and expressing interest in residual designation authority).

223. Sparse monitoring data may also be a factor. See U.S. ENVTL. PROT. AGENCY, supra note 13 , at 1 (noting the absence of monitoring data for the vast majority of river and stream miles throughout the country).

224. 33 U.S.C. § 1362(14) (2006); Rapanos v. United States, 547 U.S. 715, 743 (2006) (noting that a discharge into a conveyance system still can require a NPDES permit). 
225. Because coverage under the NPDES stormwater program depends upon population density, highly urbanized areas with low population density, like commercial districts or office parks, may not be regulated at all. See National Pollutant Discharge Elimination System-Regulations for Revision of the Water Pollution Control Program Addressing Stormwater Discharges, 64 Fed. Reg. 68722, 68751 (Dec. 8, 1999). Similarly, private, non-industrial stormwater systems are unregulated. See supra notes 118-24 and accompanying text.

226. Residual designation authority may lead to standards more directly focused on impervious cover and also would remove the buffering effect of municipalities, which serve as regulatory intermediaries under the traditional municipal stormwater permitting program. See supra notes 110-23 and accompanying text (explaining the limited requirements and circumscribed applicability of the traditional NPDES stormwater program).

227. See Virginia S. Albrecht, Clean Water Act Update, in LAND USE INSTITUTE: PLANNING, REGULATION, LITIGATION, EMINENT DOMAIN, AND COMPENSATION 347, 352 (2009) (describing recommended daily allowance as "the sleeping giant").

228. See supra Part II.B.1.

229. See Duhigg, supra note 165, at A1 (describing state agency complaints about "insufficient resources").

230. See, e.g., COMM. ON WATERSHED MGMT. ET AL., NEW STRATEGIES FOR AMERICA'S WATERSHEDS (1999); U.S. ENVTL. PROT. AGENCY, WATERSHEDBASED NATIONAL POLLUTANT DISCHARGE ELIMINATION SYSTEM (NPDES) PERMITTING TECHNICAL GUIDANCE (2007). 
231. ME. DEP'T OF ENVTL. PROT., GENERAL PERMIT - POST-CONSTRUCTION

DISCHARGE OF STORMWATER IN THE LONG CREEK WATERSHED (2009), available

at http://www.restorelongcreek.org/docs/dep_permit/dep_general_permit_corrected_11-6-09.pdf

[hereinafter LONG CREEK GENERAL PERMIT]; LONG CREEK WATERSHED

MANAGEMENT PLAN, supra note 5, at 4.

232. Regulators chose to require permits from only those landowners with at least one acre of impervious cover. LONG CREEK GENERAL PERMIT, supra note 231, at 2.

233. Id. at 8 .

234. Landowners can receive credit for stormwater control work they already have completed.

LONG CREEK WATERSHED MANAGEMENT PLAN, supra note 5, at 71-73.

235. See id., at 74-75; LONG CREEK GENERAL PERMIT, supra note 231, at 5.

236. LONG CREEK GENERAL PERMIT, supra note 225, at 8 (requiring the contract), 9-10 (describing funding and implementation); see LONG CREEK WATERSHED MANAGEMENT PLAN, supra note 5, at 26-80.

237. LONG CREEK WATERSHED MANAGEMENT PLAN, supra note 5, at 39-41, 46-60.

238. Id. at $41-42$.

239. Id. at 28-33, 43-46.

240. Participants in the Long Creek process attended, and continue to attend, dozens of meetings.

241. I heard these concerns repeatedly at public meetings and in more informal conversations. 
242. See Interview with Tamara Lee Pinard, Cumberland Cnty. Soil \& Water Conservation Dist., Windham, Me. (June 22, 2009).

243. Because property in Long Creek is largely commercial, there are fewer landowners than in a typical residential urban watershed. LONG CREEK WATERSHED MANAGEMENT PLAN, supra note 5, at 10.

244. See id. at $67-68$.

245. Id. at 68 .

246. Id.

247. See generally Arnold, supra note 16.

248. LONG CREEK WATERSHED MANAGEMENT PLAN, supra note 5, at 62-71.

249. John Richardson, Long Creek Cleanup Rolls Toward Reality, PORTLAND PRESS

HERALD, Jan. 14, 2010, at B1 (contrasting $\$ 3,000$ per-acre estimated costs for the collective permit with $\$ 7,000$ to $\$ 10,000$ per-acre costs for individual permits).

250. I base this statement on my personal observations of landowner meetings.

251. In comments on an earlier draft, Curtis Bohlen deserves credit for pointing out this dynamic.

252. See Interview with David Russell, Eng'r, Fairchild Semiconductor, S. Portland, Me. (June 17, 2009) (describing his role); Interview with Paul Ureneck, Boulos Props., Portland, Me. (July 7, 2009). 
253. I base this assertion on comments at public meetings and on extended email correspondence addressing the content of the participating landowner agreement.

254. See Interview with Tamara Lee Pinard, supra note 242 ("I learn more every day.").

255. See LONG CREEK WATERSHED MANAGEMENT PLAN, supra note 5, at 61-65.

Because of high monitoring costs, data availability may pose significant challenges for adaptive management.

256. See Interview with Steve Hinchman, supra note 220. Government officials often express a desire to incorporate some elements of the Long Creek process but to use stormwater utilities rather than permitting processes. E.g., Telephone Interview with John Murphy, Eng'r, \& Wendy Warren, Envtl. Coordinator, City of Bangor (December 17, 2009).

257. See Interview with Don Witherill, supra note 24 (noting that the approach "springs from basic watershed planning principles").

258. See, e.g., COMMITTEE ON WATERSHED MANAGEMENT ET AL, supra note 230 (advocating watershed-based management). The approach also bears some resemblance to innovations in habitat protection and wetlands permitting, where regulators also have tried using broader-scale plans to address some of the inefficiencies inherent in individual permitting approaches. See, e.g., Jessica B. Wilkinson \& Robert Bendick, The Next Generation of Mitigation: Advancing Conservation through Landscape-Level Mitigation Planning, 40 ENVTL. L. REP. NEWS \& ANALYSIS 10023 (2010) (describing several mechanisms); Bradley J. Karkkainen, Biodiversity and Land, 83 CORNELL L. REV. 1, 59-63 (1997) (describing regionalscale HCPs).

259. See ETOWAH HABITAT CONSERVATION PLAN, supra note 179. 
260. See Avi Brisman, Considerations in Developing a Stormwater Utility, 26 S. ILL. L.J. 505 (2002) (describing such programs); see also CENTER FOR WATERSHED PROTECTION, supra note 160, at 21, 23 (describing programs funded by impervious cover fees); Punam Parikh et al., Application of Market Mechanisms and Incentives to Reduce Stormwater Runoff: An Integrated Hydrologic, Economic, and Legal Approach, 8 ENVTL. SCI. \& POL'Y 133 (2005).

261. Compare Elizabeth Treadway and Andrew L. Reese, Financial Strategies for Stormwater Management, AM. PUB. WORKS ASS'N REP., Feb. 2000, at 12, 13, available at http://stormwaterfinance.urbancenter.iupui.edu/PDFs/Treadway.pdf (describing annual stormwater management costs, even for "advanced" programs, of $\$ 90$ to $\$ 150$ per acre), with LONG CREEK WATERSHED MANAGEMENT PLAN, supra note 5, at 70 (estimating annual costs of $\$ 2,500$ to $\$ 3,000$ per acre, even with the savings from collective permitting).

262. The rarity of such programs is perhaps best illustrated by the case studies on the EPA's watershed permitting page. Few actually involve efforts to address all sources in a watershed. See Watershed-Based NPDES Permitting Overview, U.S. ENVTL. PROT. AGENCY, http://cfpub.epa.gov/npdes/wqbasedpermitting/wspermitting.cfm (last visited Nov. 1, 2010) (providing links to case studies).

263. See supra notes $208-09$ and accompanying text.

264. See 33 U.S.C. $§ 1342(p)(2)(E)$ (2006) (mandating designations if the EPA "determines that the stormwater discharge contributes to a violation of a water quality standard or is a significant contributor of pollutants to waters of the United States").

265. See U.S. ENVTL. PROT. AGENCY, supra note 262 ("Watershed-based NPDES permitting ... emphasizes addressing all stressors within a hydrologically-defined drainage basin ....”). 
266. See infra Part V.A (discussing possibly excessive emphasis on highly urbanized areas).

267. See supra Part II.B.3 (discussing some innovative state and local programs); NRC, supra note 15 , at $475-555$ (advocating other reforms).

268. According to many, that abstraction represents not a failing but a stroke of genius, for it greatly reduces the informational demands placed on regulators. E.g., HOUCK, supra note 23, at 63; Wendy E. Wagner, The Triumph of Technology-Based Standards, 2000 U. ILL. L. REV. 83; Sidney A. Shapiro \& Thomas O. McGarity, Not So Paradoxical: The Rationale for TechnologyBased Regulation, 1991 DUKE L.J. 729, 739-51.

269. See supra Part II.B.1.

270. See supra Part II.B.2.

271. Section 4 of the ESA, which creates a process for assessing the status of species and allows citizen petitions to force initiation of that process, provides a useful analogy. See 16 U.S.C. § 1533 (2006).

272. The Clean Air Act's ambient air quality approach does this through its SIP requirements, which, though sometimes criticized, have produced stronger results than the CWA's water quality provisions. See Dave Owen, Probabilities, Planning Failures, and Environmental Law, 84 TUL. L. REV. 265, 280-81 (2009).

273. See John P. Dwyer, The Pathology of Symbolic Legislation, 17 ECOLOGY L.Q. 233 (1990) (describing the EPA's reluctance to implement programs it deemed overly stringent).

274. See Wagner, supra note 22 , at 193 ("[C]ompetent regulatory design requires an assessment of what science and other sources of technical information can and cannot offer."). 
275. See Bradley C. Karkkainen, Adaptive Ecosystem Management and Regulatory Penalty

Defaults: Toward a Bounded Pragmatism, 87 MINN. L. REV. 943 (2003).

276. See SHABMAN ET AL., supra note 135.

277. See HOUCK, supra note 23, at 204-05.

278. See 33 U.S.C. § 1313(d) (2006).

279. See id. § 1342(p).

280. See U.S. ENVTL. PROT. AGENCY, supra note 13, at 1 (documenting the sparse extent of monitoring).

281. See supra notes 203-04 and accompanying text. TMDLs written using traditional methods still may create sufficient documentation to trigger residual designation authority, but because traditional methods probably will not explain as clearly the links between impervious cover and degradation, the documentation is not likely to be as compelling.

282. Section 402(p) does not specify standards for sources permitted pursuant to residual designation authority.

283. See Wagner, supra note 22.

284. See Wagner, supra note 22, at 191 (describing the massive scale of the stormwater regulatory program without RDA permittees); Michael P. Vandenbergh, From Smokestack to SUV: The Individual as Regulated Entity in the New Era of Environmental Law, 57 VAND. L. REV. 515, 520 (2004) (describing common resistance to regulation of individual or household behavior). 
285. See Interview with Patrick Cloutier, supra note 3 (acknowledging that, in practice, stormwater management means controlling people's use of land).

286. See A. Dan Tarlock, Land Use Planning: The Weak Link in Environmental Protection, 82 WASH. L. REV. 651, 656 (2007); Patrick Del Duca and Daniel Mansueto, Indirect Source Controls: An Intersection of Air Quality Management and Land Use Regulation, 24 LOY. L.A.

L. REV. 1131, 1141 (1991).

287. 33 U.S.C. $§ 1251(b)(2006)$.

288. Hearing on the Nomination of Lisa P. Jackson to be Administrator of the U.S.

Environmental Protection Agency and Nancy Helen Sutley to be Chairman of the Council on Environmental Quality, Before the S. Comm. on Env't \& Pub. Works, 111th Cong. (2009) (opening statement of James Inhofe, Senate Environmental and Public Works Committee) (describing the Clean Water Restoration Act and possible ESA reforms). Older debates are filled with similar rhetoric. See, e.g., 133 CONG. REC. 1293 (1987) (statement of Sen. Dole) ("S. 1 proposes Federal land use planning. My substitute leaves it to the States."); Id. at 1569 (statement of Sen. Symms) (“This mandatory program smells of landuse planning."). In vetoing proposed legislation, President Reagan voiced similar themes: "[T]he agency will be able to become a major force in local zoning decisions that will determine whether families can do such basic things as build a new home. That is too much power for anyone to have, least of all the Federal Government." Letter from Ronald Reagan, U.S. President, to the House of Representatives (Jan. 30, 1987), available at http://www.reagan.utexas.edu/archives/speeches/1987/ 013087f.htm (entitled "Message to the House of Representatives Returning Without Approval the Water Quality Act of 1987”). 
289. See, e.g., 133 CONG. REC. 1465 (1987) (statement of Sen. Mitchell) (“[T]he distinguished minority leader referred to the nonpoint provision of this bill as 'Federal land use planning.' This is a serious charge. It is an erroneous charge."); $i d$. at 1581 (statement of Sen. Durenberger) (“[I]t was said by some that H.R. 1 was a Federal land use planning bill. ... Well, Mr. President, nothing could be further from the truth.").

290. See Cal. Coastal Comm’n v. Granite Rock Co., 480 U.S. 572, 587 (1987) (“Land use planning in essence chooses particular uses for the land; environmental regulation, at its core, does not mandate particular uses of the land but requires only that, however the land is used, damage to the environment is kept within prescribed limits."); but see id. at 602-05 (Powell, J., dissenting) (questioning this distinction).

291. Rapanos v. United States, 547 U.S. 715, 738 (2007) (“The extensive feder al jurisdiction urged by the Government would authorize the Corps to function as a de facto regulator of immense stretches of intrastate land .... [T] he Corps' interpretation stretches the outer limits of Congress's commerce power and raises difficult questions about the ultimate scope of that power.”); Solid Waste Agency of N. Cook Cnty. v. U.S. Army Corps of Eng'rs (SWANCC), 531 U.S. 159, 174 (2001) ("Permitting respondents to claim federal jurisdiction over ponds and mudflats falling within the 'Migratory Bird Rule' would result in a significant impingement of the States' traditional and primary power over land and water use.").

292. E.g., SWANCC, 531 U.S. at 191 (Stevens, J., dissenting) (“The CWA is not a land-use code; it is a paradigm of environmental regulation. Such regulation is an accepted exercise of federal power."). 
293. See, e.g., Hodel v. Va. Surface Mining \& Reclamation Ass'n, 452 U.S. 264, 275-77 (1981) (rejecting a challenge to federal mining regulation); $i d$. at 305 (Powell, J., concurring) (asserting that the Commerce Clause allows even "an extraordinarily intrusive program of federal regulation and control of land use and land reclamation, activities normally left to state and local governments").

294. The Rapanos and SWANCC decisions, for example, clearly indicate that federalism concerns will inform at least some justices' application of constitutional theories to water quality regulation, but exactly how is far from clear.

295. See Rapanos, 547 U.S. at 721 ("The burden of federal regulation on those who would deposit fill material in locations denominated 'waters of the United States' is not trivial."); see generally Daniel C. Esty, Revitalizing Environmental Federalism, 95 MICH. L. REV. 570, 62122 (1996) (noting that the proper degree of regulatory centralization and the proper degree of regulatory flexibility can be distinct issues).

296. See, e.g., United States v. Morrison, 529 U.S. 598, 599 (2000) (“The Constitution requires a distinction between what is truly national and what is truly local ...."); Gregory v. Ashcroft, 501 U.S. 452, 457-60 (1991).

297. See, e.g., Richard B. Stewart, Environmental Quality as a National Good in a Federal State, 1997 U. CHI. LEGAL F. 199, 203, 213 (describing the federal environmental law system as "burdensome, top-heavy" and asserting that the "existing system of centralized federal command-and-control regulation and liability ... displays many grievous flaws," including "excessive rigidity and cost, barriers to innovation, lack of democratic political accountability, skewed priorities, excessive delay and transaction costs, and excessive legalization"); Sunstein, 
supra note 100, at 627 ("A large source of regulatory failure in the United States is the use of rigid, highly bureaucratized 'command-and-control' regulation.”); see generally John O. McGinniss, Reviving Tocqueville's America: The Rehnquist Court's Jurisprudence of Social Discovery, 90 CAL. L. REV. 485, 490-91 (2002) (arguing that "[t]he Rehnquist Court's jurisprudence reflects a more skeptical view of centralized democracy" and strives to increase civic involvement by returning power to local institutions).

298. E.g., Hunter Lovins \& Amory Lovins, Foreword to BEYOND BACKYARD ENVIRONMENTALISM viii-ix (Joshua Cohen \& Joel Rodgers eds., 2000) (“[E]nvironmental problems . . . should be solved by people with local expertise.”); Sunstein, supra note 100, at 626 ("Local decisions inculcate a sense of responsibility in citizens and encourage participation far more effectively than centralization.”).

299. See, e.g., Richard B. Stewart, Madison's Nightmare, 57 U. CHI. L. REV. 335, 351-52 (1990). Other academics have strongly advocated devolution, however. See, e.g., Richard L. Revesz, Rehabilitating Interstate Competition: Rethinking the "Race-to-the-Bottom" Rationale For Federal Environmental Regulation, 67 N.Y.U. L. REV. 1210, 1253 (1992) (arguing that allowing state-level control is "presumptively beneficial").

300. See Friends of the Earth, Inc. v. Laidlaw Envtl. Servs. (TOC), Inc., 528 U.S. 167, 209-10, 215 (1999) (Scalia, J., dissenting) (criticizing citizen suits).

301. See Telephone Interview with Tom Blake, supra note 36 (explaining that federal and state law for years had little effect on development). 
302. Four municipalities share the watershed, but most development is in South Portland. See

Long Creek Watershed Map, RESTORE LONG CREEK,

http://www.restorelongcreek.org/maps/Long_Creek_Watershed.pdf.

303. See Telephone Interview with Tom Blake, supra note 36.

304. See THE BROOKINGS INSTITUTION, CHARTING MAINE'S FUTURE 6 (2006)

(describing the Maine "brand").

305. See Interview with Paul Ureneck, supra note 252 (“None of it worked.”).

306. ME. DEPT. OF ENVTL. PROT., supra note 5; U.S. ENVTL. PROT. AGENCY, supra note 5.

307. The state was engaged in identifying impaired urban streams and in developing new regulatory controls on stormwater. See ME. DEPT. OF ENVTL. PROT., supra note 162.

308. See Interview with Jim Hughes, S. Portland City Councilor, in S. Portland, Me. (June 17, 2009).

309. Interview with Don Witherill, supra note 24.

310. Id.; Interview with Patrick Cloutier, supra note 3.

311. Email from Tamara Lee Pinard, Stormwater Program Manager, Cumberland Cnty. Soil \& Water Conservation Dist., to author (November 16, 2010, 16:10:59 EST) (on file with author).

312. See, e.g., Interview with Don Witherill, supra note 24 (praising several landowners, and also noting the importance of Curtis Bohlen's financial work); Interview with Paul Ureneck, supra note 252 (describing the meeting as an "extremely open forum," with "no hidden agendas" and a "diverse group of participants who were trying to make it work"); Interview with David 
Russell, supra note 252 (“'[I was] extremely impressed with cooperation among municipalities."); Interview with Steve Hinchman, supra note 220 (describing the "very progressive approach" taken by South Portland, the State, and several businesses); Interview with Patrick Cloutier, supra note 3 (describing Hinchman as the "consummate attorney"); Interview with Jim Hughes, supra note 308 (mentioning the Chamber of Commerce's Chris Hall as a particularly constructive participant); Interview with Chris Hall, Greater Portland Chamber of Commerce, Portland, Me. (July 7, 2009) (describing "extraordinary efforts" to bring landowners into the dialogue); Interview with Curtis Bohlen, Casco Bay Estuary P'ship, in S. Portland, Me. (June 5, 2009) (praising CLF for simultaneously forcing and constructively supporting the process). The paid facilitator hired by the group also received universal praise.

313. See Interview with Don Witherill, supra note 24.

314. Interview with Curtis Bohlen, supra note 312; Interview with Jim Hughes, supra note 308. Pending litigation in Vermont added credibility to that threat, particularly after CLF won. See In re Stormwater NPDES Permit Petition, 910 A.2d 824 (Vt. 2006); Interview with Paul Ureneck, supra note 252 (stating that participants were aware of this litigation).

315. E.g., Interview with Don Witherill, supra note 24 (noting that the filing created discord but "probably helped the process"); Interview with Patrick Cloutier, supra note 3 (calling the filing a "bump in the road," but acknowledging that "CLF needed to keep the heat on" or risk the process falling apart).

316. See Interview with Tamara Lee Pinard, supra note 236; Interview with Don Witherill, supra note 24; Interview with Patrick Cloutier, supra note 3.

317. Interview with Jim Hughes, supra note 308. 
318. One common argument for federal intervention cites likely disparities in expertise between federal and state or local governments. See, e.g., Esty, supra note 289, at 614-17. Though clearly relevant in many circumstances, that argument does not seem applicable to this particular case study, for the expertise came almost entirely from local, state, or regional actors.

319. See, e.g., Interview with David Russell, supra note 246 (explaining that his company viewed the process as consistent with a corporate commitment to environmental responsibility); Interview with Chris Hall, supra note 312 (explaining that the local business community valued environmental quality).

320. For extensive discussion of the potential of such collaboration, see JULIA M.

WONDOLLECK AND STEVEN L. YAFFEE, MAKING COLLABORATION WORK:

LESSONS FROM INNOVATION IN NATURAL RESOURCE MANAGEMENT (2000).

321. See supra note 312.

322. A more residential watershed would create obvious difficulties, as could a watershed with a different political climate.

323. See Elizabeth Ann Rieke, The BayDelta Accord: A Stride Toward Sustainability, 67 U.

COLO. L. REV. 341, 342 (1996).

324. See KAI N. LEE, COMPASS AND GYROSCOPE: INTEGRATING SCIENCE AND POLITICS FOR THE ENVIRONMENT 24-50 (1993) (describing foundational experiments in adaptive management, which began partly in response to the Endangered Species Act).

325. See Joseph L. Sax, Environmental Law at the Turn of the Century: A Reportorial Fragment of Contemporary History, 88 CAL. L. REV. 2375, 2395 (2000). 
326. See United States v. S. Fla. Water Mgmt. Dist., 847 F. Supp. 1567, 1569 (S.D. Fla. 1992) (approving a consent decree in litigation that helped spur the Everglades restoration process), aff'd in part, rev'd in part, 28 F.3d 1563 (11th Cir. 1994).

327. See Michael C. Blumm \& Viki A. Nadol, The Decline of the Hydropower Czar and the Rise of Agency Pluralism in Hydroelectric Licensing, 26 COLUM. J. ENVTL. L. 81, 117-21 (2001) (describing the removal of the Edwards Dam).

328. See, e.g., Kirsten Engel, State and Local Climate Change Initiatives: What Is Motivating State and Local Governments to Address a Global Problem and What Does this Say About Federalism and Environmental Law?, 38 URB. LAW. 1015 (2006).

329. See, e.g., HOUCK, supra note 23 , at $63-64$ (describing nearly complete inaction on water quality planning prior to the initiation of citizen suits under the CWA); William L. Andreen, The Evolution of Water Pollution Control in the United States-State, Local, and Federal Efforts, 1789-1972: Part I, 22 STAN. ENVTL. L.J. 145 (2003).

330. See, e.g., McGinniss, supra note 297.

331. The political rhetoric sometimes seems to imply that federal involvement comes only in one overwhelming form - that there is no real distinction between federal law that creates incentives for local land use regulation and parcel-by-parcel zoning by faceless Washington bureaucrats. But, of course, there is a huge diversity of ways in which federal law can affect land use. See Esty, supra note 295, at 617 (noting that centralization does not necessarily mean uniformity).

332. See New State Ice Co. v. Liebmann, 285 U.S. 262, 311 (1932) (Brandeis, J., dissenting) ("It is one of the happy incidents of the federal system that a single courageous state may, if its citizens choose, serve as a laboratory ....”). 
333. See, e.g., Erin Ryan, Negotiating Federalism, 52 B.C. L. REV. (forthcoming 2011)

(manuscript at 4) available at $\mathrm{http}: / / \mathrm{ssrn} . c 0 m /$ abstract=1583132 (arguing that overlapping roles and ambiguous boundaries create opportunities for negotiations over both policies and the allocation of authority); William W. Buzbee, Interaction's Promise: Preemption Policy Shifts, Risk Regulation, and Experimentalism Lessons, 57 EMORY L.J. 145, 157 (2007) ("Handing all regulatory power to one actor is the antithesis of the diversity of actors called for in experimentalist literature.”); David E. Adelman \& Kirsten H. Engel, Adaptive Federalism: The Case Against Reallocating Environmental Regulatory Authority, 92 MINN. L. REV. 1796, 1796-1800 (2008); Jody Freeman \& Daniel A. Farber, Modular Environmental Regulation, 54 DUKE L.J. 795 (2005); Esty, supra note 295.

334. See, e.g., Arnold, supra note 16, at 310-11. The strongest argument for those background federal constraints, notwithstanding theoretical arguments against a "race-to-the-bottom" rationale, is practical experience with state and local governments' common deference to economic actors. See supra note 329 (citing sources exploring this tendency in the field of water quality protection); Esty, supra note 295, at 623. Even when state regulators support the goals of federal law—as I think, based on many interviews and more informal conversations, is the case with the Maine DEP staff involved with Long Creek—-they clearly welcome the EPA's willingness to play the "bad cop" and are happy to use the dynamics of cooperative federalism to defray criticism.

335. See Esty, supra note 295, at 573, 638-42; Ruhl \& Salzman, supra note 39, at 65-66.

336. Even a small watershed like Long Creek, for example, straddles four cities and feeds into a gulf shared by, and affected by the cumulative environmental practices of, multiple states and provinces. 
337. See Esty, supra note 295, at 642 n.270 ("When it comes to environmental problems, people are particularly unlikely to define themselves merely on political-jurisdictional lines, especially if these are narrowly local or state-based."). Even some of the harsher critics of the existing system emphasize this point. See, e.g., Stewart, supra note 297, at 210 ("I think we must simply conclude, as a matter of fact, that many Americans regard environmental quality as an important national good that transcends individual or local interest.").

338. See SUSANNE MEIDEL \& MELISSA EVERS, BIRCH STREAM TOTAL MAXIMUM DAILY LOAD (TMDL) 8 (2006).

339. Birch Stream discharges into Kenduskeag Stream, which is an important community resource. See Visiting Bangor, Recreation, CITY OF BANGOR, ME., http://www.bangormaine.gov/vb_recreation.php (last visited Feb. 10, 2010).

340. Telephone Interview with John Murphy, Assistant City Manager, City of Bangor. Me. (January 5, 2010).

341. MEIDEL \& EVERS, supra note 338.

342. Interview with John Murphy \& Wendy Warren, supra note 256.

343. CTR. FOR WATERSHED PROT., supra note 15, at 21; Thomas R. Schueler, Implications of Impervious Cover Model: Stream Classification, Urban Subwatershed Management and Permitting, 8, 11-16 (Chesapeake Stormwater Network, Technical Bulletin No. 3, 2008), available at $\mathrm{http}: / / \mathrm{www} . c h e s a p e a k e s t o r m w a t e r . n e t /$ allthingsstormwater/thereformulatedimperviouscovermodel.html.

344. NRC, supra note 15 , at 546-47. 
345. Id. at 5-6, 90-93; SHABMAN ET AL., supra note 135, at 6-7, 25 (arguing that evaluation of water quality goals should sometimes be implemented into the TMDL process).

346. Basic Information: Introduction to Use Attainability Analyses, U.S. ENVTL. PROT. AGENCY, http://www.epa.gov/waterscience/standards/uses/uaa/info.htm (last visited Jan. 19, 2010) [hereinafter EPA Basic Information]; U.S. ENVTL. PROT. AGENCY, supra note 230, at 5 (“A watershed permitting analytical approach also considers watershed goals during the permitting process.”).

347. See William F. Swietlik, Urban Aquatic Life Uses-A Regulatory Perspective, in LINKING STORMWATER BMP DESIGNS AND PERFORMANCE TO RECEIVING WATER IMPACT MITIGATION 163, 163 (Ben R. Urbonas ed., 2001).

348. See generally Dwyer, supra note 273 (arguing that "symbolic" legal standards lead to poor resource allocation, or, if they are ignored - as they are likely to be - to polarized and stunted public debates).

349. See Schueler, supra note 343, at 16.

350. Wenger et al., supra note 14, at 1092; see also The Economics of Watershed Protection, in THE PRACTICE OF WATERSHED PROTECTION 469 (T. Schueler \& H. Holland eds., 2000).

351. See Interview with Curtis Bohlen, supra note 312; Interview with Zachary Henderson, Watershed Scientist, Woodard \& Curran, in Portland, Me. (June 29, 2009).

352. See, e.g., Bruce Ramsey, The Instructional Tale of the Million-Dollar Fish, SEATTLE TIMES, Nov. 21, 2001, at B6 (quoting SeattleTacoma airport executive involved in mitigating a 
runway expansion's impacts on salmon: "Probably per fish, it is the most expensive mitigation project known to mankind.”).

353. CENTER FOR WATERSHED PROTECTION, supra note 15, at 22 (“[R]evised water quality standards are urgently needed to support smart growth efforts.”).

354. See Schueler, supra note 343, at 4-6 (describing some regulatory mechanisms to manage impervious cover).

355. See, e.g., Durbin, supra note 180; Greenwood v. Mayor of Twp. of Hopewell, 2008 WL 3462431, at*1 (N.J. Super. Ct. App. Div., Aug. 14, 2008) (upholding a large lot size ordinance). 356. U.S. ENVTL. PROT. AGENCY, PROTECTING WATER RESOURCES WITH HIGHERDENSITY DEVELOPMENT (2006); Arnold, supra note 61, at 28 (explaining the water quality impacts of sprawling development); see also ROBERT W. BURCHELL ET AL., COSTS OF SPRAWL-2000 (2002).

357. See, e.g., CENTER FOR WATERSHED PROTECTION, supra note 15, at 22 (“[A]dded costs can quickly become a powerful barrier to desired redevelopment.”).

358. See generally Joel B. Eisen, "Brownfields of Dreams"?: Challenges and Limits of Voluntary Cleanup Programs and Incentives, 1996 U. ILL. L. REV. 883, 890-913.

359. See Hye Yeong Kwon, An Introduction to Better Site Design, in THE PRACTICE OF WATERSHED PROTECTION, 253, 253-61 (Thomas R. Schueler \& Heather K. Holland eds., 2000) (describing watershed protection techniques, many with obvious benefits for habitat preservation or air quality protection). 
360. See Interview with Don Witherill, supra note 24 (stating that the Maine DEP lacks the resources to repeat the Long Creek process for all of its impaired urban streams).

361. The Long Creek process, for example, used section 319 grants and stimulus funding, and stimulus funding also supported Bangor's efforts to restore Birch Stream. Interview with Patrick Cloutier, supra note 3; Interview with John Murphy \& Wendy Warren, supra note 256.

362. See Thompson, supra note 190, at 204 ("Both cost and resource considerations significantly limit the number of citizen suits ....”).

363. See generally Bernhardt and Palmer, supra note 34, at 742 (describing disproportionate allocation of financial resources to urban waterways).

364. A perceived crisis may be necessary for judges to be willing to intervene, given normal judicial deference to agency decisions.

365. See, e.g., CENTER FOR WATERSHED PROTECTION, supra note 15, at 21 ("“S]tates have authority to create more achievable standards for non-supporting streams ...."); Swietlik, supra note 347 (describing mechanisms).

366. 33 U.S.C. $§ 1313(a)$, (c) (2006). The standards must include "designated uses of the navigable waters involved and the water quality criteria for such waters based upon such uses." Id. § 1313(c)(2)(A); see 40 C.F.R. § 131.10 (2010); Pedersen, supra note 144, at 92-94.

367. 33 U.S.C. § 1313(c)(1).

368. 40 C.F.R. $\S 131.10(\mathrm{~g})$. 
369. 33 U.S.C. $\S 1313(d)(1)(A)$. Subsection (d)(1)(C) suggests that the priority rankings should be used in determining which water bodies first receive TMDLs and that the rankings could also plausibly be used to prioritize protection and restoration efforts.

370. See id. § 1313(a)(3) (setting deadlines).

371. See Jeffrey M. Gaba, Federal Supervision of State Water Quality Standards Under the Clean Water Act, 36 VAND. L. REV. 1167, 1194-95 (1983).

372. See SHABMAN ET AL., supra note 135, at 20 ("Most states began by adopt ing the CWA goals of fishable and swimmable uses to be attained statewide ...."); Paul L. Freedman et al., Factors for Success in Developing Use Attainability Analyses, 2 WATER PRAC. 1, 3 (2008). 373. See, e.g., GENERAL ACCOUNTING OFFICE, WATER QUALITY: INCONSISTENT STATE APPROACHES COMPLICATE NATION'S EFFORTS TO IDENTIFY ITS MOST POLLUTED WATERS 7 (2002) (describing Virginia's designation of all state waters-even those too shallow to swim - as swimmable).

374. See 33 U.S.C. § 1251(a)(1)-(2); Jedediah Purdy, The Politics of Nature: Returning Democracy to Environmental Law, 119 YALE L.J. 1122, 1180-87 (2010) (explaining that Congress knowingly chose ambitious and perhaps unattainable goals and that key supporters favored this approach as a method of emphasizing the social importance of clean water and expanding the realm of the possible).

375. See, e.g., ME. REV. STAT. tit. 38, § 465 (2010) (setting standards). Even the lowest classification requires "receiving waters ... of sufficient quality to support all species of fish indigenous to the receiving waters and maintain the structure and function of the resident biological community.” Id. § 465(4)(C). 
376. See supra Part II.A.

377. See U.S. DEP'T OF HOUS. \& URBAN DEV., THE STATE OF THE CITIES 2000, at x (2000) (noting that "land is being consumed at twice the rate of population growth"); ANDRES DUANY ET AL., SUBURBAN NATION: THE RISE OF SPRAWL AND THE DECLINE OF THE AMERICAN DREAM 7-12 (2000) (chronicling shifting development patterns and their consequences).

378. See 40 C.F.R. § 131.12 (2010); Fla. Pub. Interest Research Grp. Citizen Lobby, Inc. v. EPA, 386 F.3d 1070, 1073-74 (11th Cir. 2004).

379. 40 C.F.R. $\S 131.10(\mathrm{~g})$. In setting water quality standards, states must designate specific uses-for example, fishing, contact recreation, non-contact recreation, or drinking water supply—that each waterway will support. See 40 C.F.R. $\S 131.10$. Each state must then establish water quality criteria that will measure whether water quality is adequate to support those designated uses. Pedersen, supra note 144, at 92-93.

380. 40 C.F.R. $\S 131.10(\mathrm{~g}),(\mathrm{h})(1)$.

381. Memorandum from Kenneth M. Mackenthum, Dir., Criteria \& Standards Div., to James A. Rogers, Assoc. Gen. Counsel, Water Quality Division (May 23, 1978) (on file with author); Freedman et al., supra note 372, at 2-3.

382. See 40 C.F.R. $\S 131.10(\mathrm{~g})(6),(\mathrm{h})(2)$.

383. See, e.g., Kan. Natural Res. Council v. Whitman, 255 F. Supp. 2d 1208, 1213 (D. Kan. 2003) (explaining the reasons for this presumption); Idaho Mining Ass'n v. Browner, 90 F. Supp. 
2d 1078, 1088-92 (D. Idaho 2000) (upholding reliance on this presumption). Pervasive uncertainty about the possible extent of restoration makes this presumption rather important.

384. See EPA Basic Information, supra note 346.

385. Freedman et al., supra note 372, at 1; Brooks Meredith Smith \& Andrea West Wortzel, Environmental Law, 42 U. RICH. L. REV. 383, 388-89 (2007) ("These rules . . a are rarely used, in part due to questions about process.").

386. Id.; Freedman et al., supra note 372, at 1-2.

387. See, e.g., Kan. Natural Res. Council, 255 F. Supp. 2d. at 1213 (rejecting the EPA's acquiescence to this approach).

388. See, e.g., Fla. Pub. Interest Research Grp. Citizen Lobby, Inc. v. EPA, 386 F.3d 1070, 1075 (11th Cir. 2004).

389. See, e.g., Nw. Envtl. Advocates v. EPA, 268 F. Supp. 2d 1255 (D. Or. 2003) (rejecting the EPA's approval of some of Oregon's standards); Kan. Natural Res. Council, 255 F. Supp. 2d at 1210-11 (describing the EPA's rejection of some of Kansas's standards).

390. See GENERAL ACCOUNTING OFFICE, supra note 373 (generally discussing the variety of monitoring and standard-setting approaches).

391. HOUCK, supra note 23, at 11-48 (describing the history of the TMDL program).

392. See, e.g., FPL Energy Me. Hydro LLC v. Dep't of Envtl. Prot., 926 A.2d 1197, 1198-1201 (Me. 2007) (discussing the EPA's rejection of an attempted downgrade).

393. See, e.g., Miccosukee Tribe of Indians of Fla. v. United States, 2008 WL 2967654, at *1-2 (S.D. Fla. July 29, 2008) (accusing the EPA of turning a "blind eye" to Florida's efforts to 
circumvent the normal process for amending water quality standards); Defenders of Wildlife v. Browner, 909 F.Supp. 1342, 1346-49 (D. Ariz. 1995) (chronicling a protracted history of state non-performance and federal acquiescence).

394. See generally Daniel A. Farber, Taking Slippage Seriously: Noncompliance and Creative Compliance in Environmental Law, 23 HARV. ENVTL. L. REV. 297, 298-99 (1999).

395. See Nat'l Cable \& Telecomms. Ass'n v. Brand X Internet Servs., 545 U.S. 967, 981-82 (2005) (explaining that policy changes are a normal part of administrative governance). The new interpretation must be adequately explained and reasonably consistent with the statute, but the broad statutory language upon which the EPA's anti-degradation requirements are based should permit some adjustment, so long as the new approaches still promote improvements in water quality. See Pedersen, supra note 144, at 79 (discussing these provisions); Gaba, supra note 371, at 1195-96, 1198-1200 (same). Both Pedersen and Gaba conclude that the EPA's regulatory prohibitions on downgraded water quality standards represent a somewhat strained reading of the act, which establishes general requirements that water quality standards "enhance" water quality and serve the overall purposes of the Act, but does not contain any more explicit prohibition on downgrades. See Pedersen, supra note 144, at 79; Gaba, supra note 371, at 1195-96, 11981200; see also 33 U.S.C. $§ 1313$ (c) (2006). My view is more sympathetic to the EPA's current interpretation, which I think is a perfectly reasonable interpretation of some ambiguous statutory language, but I agree with Pedersen and Gaba that other interpretations are possible. Adopting an interpretation that allows greater flexibility should also be within the EPA's discretion, so long as the broader goal of water quality improvement is clearly served.

396. See supra note 256 and accompanying text (describing some of the reactions to the Long Creek process). 
397. See generally ALDO LEOPOLD, A SAND COUNTY ALMANAC 217-69 (Oxford Univ. Press ed. 1966).

398. See Interview with Don Witherill, supra note 24 (describing the Long Creek process as a wakeup call for other areas); Interview with Patrick Cloutier, supra note 3 (stating that, partly in response to the Long Creek process, South Portland has developed improved stormwater regulations for the whole city); Interview with Tamara Lee Pinard, supra note 242 (describing other initiatives).

399. The availability of this information could change if urban stream research ceases to be a field populated almost entirely by natural scientists and engineers. There is important work for economists and social scientists, among others, to do.

400. See Wenger et al., supra note 14, at 1085 (identifying as a key research question: "How do structure and function in urban streams combine to produce ecosystem goods and services, and how do those services map to those desired by the public and decision makers?"); Walsh et al., supra note 46, at 716 ("Sometimes, value placed in such altered, unnatural environments can be a product of people not missing what they never had ....”).

401. See Wenger et al., supra note 14, at 1085 (identifying questions about the feasibility and cost of restoration); Interview with Curtis Bohlen, supra note 312 (acknowledging uncertainty about the effectiveness of the Long Creek cleanup).

402. See, e.g., Lynne Y. Lewis et al., Dams, Dam Removal and River Restoration: A Hedonic Property Value Analysis, 26 CONTEMP. ECON. POL'Y 175 (2008); John Loomis et al., Measuring the Total Economic Value of Restoring Ecosystem Services in an Impaired River Basin: Results from a Contingent Valuation Survey, 33 ECOLOGICAL ECON. 103 (2000). 
403. I have found just one forthcoming article, which focuses primarily on the value of recreational spaces adjacent to streams in Seoul, Korea. See Hyunhoe Bae, Valuing the Urban Stream Attributes Using Conjoint Analysis Method, URBAN FORESTRY AND URBAN GREENING (forthcoming).

404. See NRC, supra note 15, at 546-47 (suggesting this approach). Of course, lightly developed watersheds still may be degraded by agricultural use.

405. See Lord et al., supra note 38; see also CTR. FOR WATERSHED PROT., supra note 15, at 21-22 (noting that political support for watershed restoration is often strongest in "moderately to highly developed watersheds"). There may also be more money for restoration in highly urbanized areas because more landowners could be subjected to permitting requirements.

406. See MANCUR OLSON, JR., THE LOGIC OF COLLECTIVE ACTION: PUBLIC GOODS AND THE THEORY OF GROUPS 127 (1965) (arguing that small, discrete groups with focused interests will wield disproportionate political interests); DANIEL A. FARBER \& PHILIP P. FRICKEY, LAW AND PUBLIC CHOICE: A CRITICAL INTRODUCTION 17-21 (1991) (describing public choice theory, which generally posits that legislators and other government actors act primarily in response to the self-interested advocacy of interest groups).

407. See Esty, supra note 333, at 598 ("The more uncertain, technically complex, and nonintuitive the policy choice, and the greater the difficulty in reducing the decision to easily understood dollar terms, the higher the risk of special interest distortions.").

408. See William W. Buzbee, Urban Sprawl, Federalism, and the Problem of Institutional Complexity, 68 FORDHAM L. REV. 57, 89-90 (1999) (discussing a similar dynamic in the context of transportation planning). 
409. See Arnold, supra note 16, at 292.

410. See Barton H. Thompson, Tragically Difficult: The Obstacles to Governing the Commons, 30 ENVTL. L. 241, 256-65 (2000) (describing psychological tendencies that pose challenges for environmental management). The endowment effect is a common tendency to place a higher value on things we have than on seemingly equivalent things not in our possession, and therefore to demand more compensation for relinquishing something than one would pay to acquire it. Hyperbolic discounting is the tendency to severely undervalue future assets. See id.

411. See Walsh et al., supra note 46, at 716 ("Sometimes, value placed in such altered, unnatural environments can be a product of people not missing what they never had ....”); but see Interview with Don Witherill, supra note 24 (noting that memories of fishing and swimming in the Long Creek watershed influenced the process).

412. See Oliver A. Houck, On the Law of Biodiversity and Ecosystem Management, 81 MINN. L. REV. 869, 883-84 (1997) (“Tough odds call for precise law.”). Two South Portland city councilors-Tom Blake and Jim Hughes_-told me a story that illustrates this point. Interview with Jim Hughes, supra note 308; Telephone Interview with Tom Blake, supra note 36. Both recalled an early Long Creek meeting at which someone asked what would happen if Long Creek could not be cleaned up; would there be flexibility? Maine DEP Commissioner David Littell, who had been sitting in the audience, then spoke up and said that the CWA left no choice but to restore the creek to fishable, swimmable quality, so those goals simply would have to be achieved. Both Blake and Hughes viewed this statement as important for fixing the participants' resolve and making the process successful.

413. 33 U.S.C. $\S 1313(d)(2006)$. 
414. See 40 C.F.R. § 131.10(g) (2010).

415. See ENVTL. PROT. AGENCY, supra note 262.

416. I am currently involved in an ongoing interdisciplinary research project that will include evaluation of this hypothesis.

417. Specifically, these changes would require some revision of the EPA's regulations.

418. By current uses, I mean present uses. But see Mackenthum Memorandum, supra note 381.

419. I suggest this constraint because of the collective action problems discussed above, see supra note 409 and accompanying text, and because almost all communities value their larger waterways.

420. See Wenger et al., supra note 14, at 1085.

421. See generally Purdy, supra note 374 (observing that environmental values are not static and can evolve through democratic processes).

422. Cost-benefit analysis is one potentially helpful tool, but, as reams of articles have pointed out, regulatory costs may be somewhat more easily monetized than benefits, and the analyses therefore could skew rather than improve decisionmaking. E.g., Ackerman \& Heinzerling, supra note 41 , at $1557-58$.

423. See supra note 92 and accompanying text.

424. Because few urban streams have been restored, there have not been many opportunities to collect data. 
425. See Charles River Watershed, MASS. EXEC. OFFICE OF ENERGY \& ENVTL.

AFFAIRS, OFFICE OF WATER POLICY, http://www.mass.gov/envir/ (follow “Air, Water \& Climate Change hyperlink; then follow "Preserving Water Resources" hyperlink; then follow "Massachussetts Watersheds" hyperlink; then follow "Charles River Watershed" hyperlink.) (last visited Nov. 1, 2010).

426. $I d$.

427. U.S. ENVTL. PROT. AGENCY, supra note 37, at 3.

428. Id.

429. See THE STANDELLS, DIRTY WATER (Tower/Capitol Records 1966); Editorial, Clean Politics: Bush Takes the Lead on Environmental Issues, DALLAS MORNING NEWS, Sept. 2, 1988, at 30A (discussing George H.W. Bush's use of the "super-polluted" Charles River to attack Michael Dukakis’s environmental credentials).

430. See Charles River History, CHARLES RIVER WATERSHED ASS'N, http://www.crwa.org/cr_history.html (last visited Nov. 1, 2010).

431. U.S. ENVTL. PROT. AGENCY, supra note 37, at 9-10 (“'[T]he Lower Charles River often violates water quality standards for the designated recreational and aquatic life uses.”).

432. Id.

433. Id. at 1 .

434. An expanded designation may still occur. See Telephone Interview with William WalshRogalski, Counsel for Special Projects, EPA Region 1 (June 29, 2009) (noting that CLF 
had threatened to petition for residual designation of the entire Charles River watershed and the adjacent Neponset and Mystic River watersheds).

435. See generally Lord et al., supra note 38; RIVERTOWN: RETHINKING URBAN RIVERS (Paul Stanton Kibel ed. 2007). 